\title{
STUDIES ON RESPIRATORY MECHANISMS OF THE SALAMANDER PSEUDOBRANCHUS STRIATUS
}

By

JOHN RICHARDSON FREEMAN

\begin{abstract}
A DisSeRTATION PRESENTED TO THE GRADUATE COUNCIL OF THE UNIVERSTTY OF FLORIDA

IN PARTIAL FULFILLMENT OF THE REQUIREMENTS FOR THE DEGREE OF DOCTOR OF PHILOSOPHY
\end{abstract}

UNIVERSITY OF FLORIDA

December, 1963 
ACKNOWLEDGMENTS

I wish to express appreclation to Dr. Coleman J. Goin, Chalrman of my Supervisory Committee and the other members of my committee, Drs. G. R. Noggle, J. H. Gregg, J. W. Brookbank, and F. G. Nordlie for their suggestions concerning the study and for reading and critlcizing the manuscript.

I wish to thank Mr. Keith Butson of the U. S. Weather Bureau for climatological data from the Gainesville area. I thank Mrs. Ruth Smith for her cooperation in securing equipment necessary for the study. Many fellow students have helped in the field and in the laboratory on many occasions and most special appreciation is due Miss Charlotte Cantrell and Mr. C. G. Jackson for their encouragement, fldelity, and support during the past jear.

I wish to thank the Department of $\mathrm{Blolog}$, the College of Arts and Sclences, and the Department of Blological Sciences for Pinancial aid. Finally, I wish to express appreciation to the University of Chattanooga for a leave of absence in order to complete this study. 
ACKITOWLEDGMEITSS . . . . . . . . . . . 11

IIST OT TABLES. . . . . . . . . . . . v v

IIST OF FIGURES .............. v1

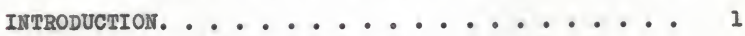

General Consideration of Amphibian Respiration .. 1

Pseudobranchus ............. 5

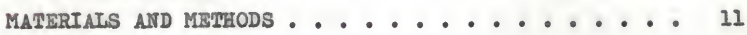

Collecting Methods ............ 11

Maintenance of Animals in the Laboratory ..... II

Physical Invironment of the Hyacinth Ponds . . . 12

Aquatic Respiration and Temperature. ...... 13

Fffects of Carbon D1oxide and Oxggen on

Resplratory Behavior........... 15

Frythrocjte Count. . . . . . . . 17

firythrocyte s1ze................. 17

Hemoglobin Value . . . . . . . . 18

RESULTS ......................... 19

Physical Conditions of Prairie Ponds...... 19

Aquatic Resplration and Temperature. . . . . 22

Iffects of Carbon Dioxide and OxJgen

Concentrations on Resplratory Behavior. . . . 22

Erythrocjte Count. . . . . . . . . . 31

Brythrocyte size............. 31 
Page

Hemoglobin Value . . . . . . . . 32 prscussion. ................. 34

Physical Conditions of Hyacinth Ponds. . . . 34

Oxggen Consumption and Temperature...... 42

Effect of Oxggen and Carbon Dioxide on

Respiratory Behavior......... 47

Brythrocyte size and count ......... 57

Hemoglobin Values. . . . . . . . 66

SUMMARY ........................ 71

IITERATURE CITED. . . . . . . . . . . 74

BIOGRAPHICAI SKBTCH ............... 79 


\section{IIST OF TABLES}

Table

1. Temperature Readings of Hyacinth Ponds ... 20

2. Oxygen Consumption Rate of Pseudobranchus at 15 Degrees Centigrade. . . . . 24

3. Oxggen Consumption Rate of Pseudobranchus at

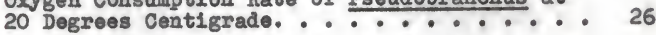

4. Oxggen Consumption Rate of Pseudobranchus at 25 Degrees Centigrade. . . . . . . 28

5. Climatological Data from the Gainesville Area, April, 1963........................ 37

6. Climatological Data from the Gainesville Area, May, 1963..................... 39

7. Temperatures and Oxygen Consumption Rates. - 44

8. Irythrocyte Count in Amphibians. ..... 58

9. Erythrocyte size in Amphiblans...... 60

10. Erythrocyte S1ze and Count in Amphibians ... 62

11. Hemoglobin Content of Amphibian Blood. ... 67 
1. Temperature readings of the air, open water, and sub-hyacinth water of a prairie pond during April and Mag of 1963........ 21

2. Oxggen and carbon dioxide concentrations in open water and sub-hyacinth water in April and May of 1963.................

3. Resplratory behavior of Pseudobranchus at different concentrations of oxygen and carbon

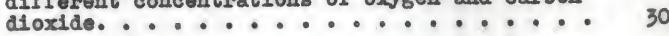

4. Brythrocyte size in Pseudobranchus ...... 33

5. Analjsis of oxpgen consumption and temperature 45

6. Pseudobranchus in water with oxjgen concentration of 7.7 parts per million...

7. Same animal in water with oxggen concentration of 2.8 parts per million....

8. Pseudobranchus after prolonged retention in water of oxygen concentration of less than one part per mililon .............

9. Same animal, enlarged vlew .......... 


\section{INTRODUCTION}

\section{General Consideration of Amphibian Respiration}

The Anphibia have been accorded an interest by blologists disproportionate to their rank as the smallest class of tetrapods. This is due to the fact that the Amphibia show the characteristics of ontological and phylogenetic transition from aquatic to terrestrial existence. This unique position among the vertebrates in being adapted to two very different environments, land and fresh-water, is emphasized by all aspects of amphibian b10logy. Adaptation in respiratory morphology, physiology, and behavior are important characteristics that make any amphibian suited to the environment in which it is found. The comparative physiology and morphology of respiratory mechanisms of both invertebrates and vertebrates has been treated by Krogh (1941). General information on respiration in the Amphibia is Pound in Noble (1931) and Angel (1947). The anatomy and evolutionary significances of the respiratory organs of amphibians have been discussed by Smith (1960) and Goin and Goln (1962). Since the Amphibia exploit two media, air and water, for external respiration the organs of gas exchange are varied in 
structure and usage. The integument and buccopharyngeal epithellum are used in both air and water, while the lungs are used in aerial respiration and the external gills are used in aquatic respiration.

Krogh (op. cit.) delimits gills as those appendages which have no other major function except aquatic resplration. This definition is valid for the many varied structures called gills in invertebrates, but in the amphibians only those paired structures that are found in the branchlal reglon should be called true g1lls. This obviously would exclude integumentary growths such as the papillae of Astylosternus and the skin folds of cryotobranchus and Telmatoblus Prom this category, although these structures are vascularized and utillzed for respiration. Gills are present at some stage in the life history of all amphiblans except for those few which do not have an aquatic larval stage. Most amphibians metamorphose but the gllls persist in sexually mature forms which were formerly referred to as the Perennibranchiata. This was not a natural group but members of several taxa which can be divided Into two groups, the neotenic salamanders and the paedogenic perennibranchs. The neotenic salamanders Include many ambystomids and some plethodontids. They metamorphose in response to the activation of their thrrold glands by lodine treatment or temperature change. Paedogenic 
perennibranchs including the sirenids, proteids, and some plethodont1d are not so stimulated to metamorphose but are genetically controlled to retain their gills beyond the 1mmature stage.

The size, structure, and utilization of gills in larval forms of perennibranchs have been considered to be in direct relation to the oxpgen content of the water (Noble, 1931 and Angel, 1947). The larvae of those species of salamanders or frogs which develop in water of low oxygen tension show the largest and most ramified gills and those larval forms of species found in well aereated conditions generally show greatly reduced gills. Conant (1958) sajs of the perennibranch Necturus maculosus, "Size and condition of gills, although subject to individual variation, usually replect onvironment. They are most i1kely to be large, bushy, and kept in motion if the water is foul or warm; usually they are small and contracted if the water is cool and contains conslderable oxggen in solution."

The lungs of amphibians vary greatly in s1ze and structure. They are absent in salamanders of the family Plethodontidae and the brook species of the genus Hynoblus. In Phracotriton and Salamandrina which are both found in well aereated cool streans the lungs are greatly reduced in size. The lungs of the cold stream-dwelling anuran Ascaphus 
are much smaller than those of other frogs and toads. Such reductions in lungs are correlated with increased cutaneous or buccopharyngeal respiration.

In the caecilians the left lung is usually rudimentary, supposedif correlated, as in snakes, with their elongated body form. However, in other elongated amphibians such as Amphlume, Siren, and Pseudobranchus both lungs are equally well developed.

The lungs of anurans show increased complexity of internal structure in the predominantly terrestrial forms. The arier skin of terrestrial animals and subsequent reduction of cutaneous respiratory surface necessitates a corresponding increase of internal respiration.

Cutaneous respiration takes place to some degree in all amphibians. It is the main form of gaseous exchange In those animals which have no lungs, those with reduced lungs, or in anurans which are hibernating in the bottoms of ponds or lakes. Buccopharyngeal respiration is most important to the lungless active terrestrial salamanders in which additional surface area is needed to supplement the gas exchange through the integument. It is also utilized by other forms. I have had a Cryptobranchus alleganiensis under observation for over three jears and it uses 1ts buccopharyngeal opithelium for both aerial and aquatic respiration. Most of the time the animal remains 
submerged and in order to supplement its cutaneous respiration it draws water through 1ts nostrils into its mouth carlty bringing about a distension of 1 ts gular skin. When it does surface it draws air through its nostrils or mouth and either retains it in its buccopharyngeal carity, again distending the gular region, or forces the air into the lungs which buojs the animal to float at the surface. The lunged perennibranchs represent that group of amphibians which utilize all of the respiratory structures of amphibians in a single individual. Thus a study of the respiration of a lunged perennibranch would field information on all phases of amphibian respiration. Because of its availability in the Gainesville area, its relatively easy maintenance in the laboratory, and 1ts intermediate size as an amphibian, Pseudobranchus striatus axanthus was selected as the perennibranch for this study.

\section{Psoudobranchus}

The perennibranch amphibians of the family sirenidae are generally classified under the suborder Meantes in the order Caudata (Urodela). Recently, however, Goin and Goin (op. cit.) have reinstated the order Mrachystomata thus separating the two living genera Siren and Pseudobranchus and the several fossil genera of the sirenidae from the rest of the tailed, legged amphibians. 
There is only one living spectes of the dwart siren, Pseudobranchus striatus. Five subspecies have been described, ‥ S. Striatus Leconte, ‥ s. axanthus vetting and Goin, ․ S. Bpheniscus Goin and Crenshaw, ‥ S. Iustricolus

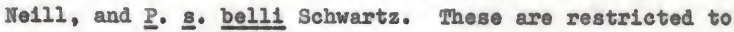
the extreme southeastern United States with $\underline{P}$. . axanthus occupying most of the peninsula of Florida and intergrading with all of the other subspecies. Goin and Auffenberg (1955) recognlze two extinct species, Pseudobranchus robustus from the Pleistocene of Norida based on five vertebrae and Pseudobranchus vestustus from the Pllocene of Florida based on six vertebrae.

In the geographic range of Pseudobranchus where the water hyacinth Ilchornia crassipes has been introduced, the hjacinth comuntiles of prairle ponds, sloughs, and ditches are the most important habitat of this species (Goln, 1943 and Conant, 1958). The flbrous root system of the hyacinths supports dense populations of the invertebrates which serve as a food supply for Pseudobranchus and at the same time offer refuge for Pseudobranchus from its predators such as the warmouth bass Chaenobryttus coronarius or the mud snake Farancia abacura. Pseudobranchus eggs are laid singly or in clutches of up to five eggs on the upper portions of the hyacinth roots. Carr (1940) reports finding Pseudobranchus eggs throughout the spring months attached 
to the Pllamentous leaves of Cabomba and Ceratophyllum as well as water hyacinth roots. Goln (1941) found Pseudobranchus eggs from April to November and during wot years I have collected Pseudobranchus eggs in every month with the heaviest egg-laving period being the latter half of September and early October in the Gainesville, Mlorida area. In areas devold of hyacinths where Psoudobranchus has been found such as the Gulf Hammock region of peninsular Florida, its habitat is the muckg bottom of bog areas into which they retreat at the least disturbance (Neill, 1951). Noble (op. cit.) describes Pseudobranchus as a burrowing salamander and field observation by Harper (1935) and Freeman (1958) attest to this habit of Pseudobranchus when under drying conditions.

The floating hyacinth community can be thought of as a relatively recent habitat of the burrowing mud-dwelling Pseudobranchus which itself has been around since the pliocene. It offers food supply, shelter, and egg-laying areas which before the introduction of the hyacinth were probably provided by two habitats, the muddy bottoms of ponds and filamentous parts of aquatic regetation. The advantage of an eel-shape to mud-dwelling amphibians is obvious to any collector who has watched Amphluma, Siren, or Pseudobranchus wriggle from his grasp and disappear into the muck. The vestigial legs of Amphiuma 
seem of little use to the animal but the limbs of Siren, and Pseudobranchus, though only two in number, seem to serve the joung animals for balance and support and serve the adults as feeble aids in burrowing, swimming, and crawling through the hyacinths. These anterior limbs of Pseudobranchus are proportionally smaller than those of Siren and have three toes each compared to the four toes found in Siren. The other distinctive external morphological character of the Sirenidae, the gills, will be discussed later. The Sirenidae differ from other caudate amphibia by lacking maxillary bones and cloacal glands. They possess a Jacobson's organ and the lungs are elongated, well rascularized and have small septa thus giving the animals an effective internal respiratory surface. Pseudobranchus differs from Siren in size and body proportions. It is a genus of slimmer animals and reaches a maximum length in largest subspecies, ‥ ‥ axanthus, of only $250 \mathrm{~mm}$ (Freeman, 1959), while the largest known Siren lacertina measured. $950 \mathrm{~mm}$ in length (Goin, 1961).

Most of the investigations of the biology of the genus Pseudobranchus have been of a taxonomic nature. Its close association with the water hyacinth community has been noted by numerous herpetologists and ecologists. Various phases of its natural history have been cited by Noble (1931), Carr (1940), Goin (1941), B1shop (1947), 
Conant (1958), Cochran (1961) and Goin and Go1n (1962). However, few references to physiological research in this genus are avallable.

Noble and Richards (1932) implanted pituitary glands in ten female Pseudobranchus to induce ogg-iajing and Goin (1941) excised the gills of several animals and observed the respiratory behavior of these individuals. Iittle other experimental work has been done on members of the genus.

It was thought that a study of respiration in Pseudobranchus with both physiological and ecological considerations would be a contribution to the knowledge of the biologj of amphibians. Such a study would include an investigation of the blood as well as the respiratory organs of Psoudobranchus.

Some characteristics of the blood of organisms that have been shown to be related to respiration are red blood cell sizes and numbers, hemoglobin values, and oxpgen dissociation curves of the blood or of the hemoglobin. None of these had been investigated in Pseudobranchus.

As Pseudobranchus is active throughout the year and subjected to considerable changes in temperature, a studj of the relationship between oxjgen consumption and temperature was considered important. The relative utilization of the arailable respiratory surfaces of Pseudobranchus at different tensions of oxpgen and carbon 
dioxdde under experimental conditions would indicate how the animals respond to changes in dissolved respiratory gases in their environment.

Information gained concerning $\mathrm{pH}$, temperature, and dissolved oxggen and carbon dioxide under the hyacinth mats and in the open areas of ponds was needed to indicate some of the environmental conditions encountered by Pseudobranchus. 


\section{MATBRIALS AND METHODS}

\section{Collecting Methods}

Specimens of Pseudobranchus striatus axanthus were collected from the hyacinth ponds of Payne's Prairie six miles southwest of Gainesville, Alachua County, Florida. If the water levels of the ponds were sufficiently high for the hyacinth mats to float Ireely, a screen dredge scooped under the roots of the plants flelded a good catch of Preudobranchus (Goin, 1942). When the water level was too low for effective dredging, Pseudobranchus were found In the mud underneath the stranded hyacinths on the periphery of the ponds. Here a potato rake was used to scrape back the hracinths and mud to reveal the burrowing Pseudobranchus and the animals were seized by hand or captured in a dip net.

\section{Maintenance of Animals in the Laboratory}

The experimental animals were housed singly or in small groups in spring water or filtered pond water at room temperature in one-gallon jars or three-gallon glass aquaria. It was found that the animals did not fare as 
well in aged tap water, perhaps because of the added Pluorides and chloramine.

The Pseudobranchus were fed about twice a week on aquatic oligocheetes, chironomid larvae, or the white worm Bnchytraeus. No other maintenance was needed except an occasional change of the water in the containers. One Pseudobranchus lived for four jears under such conditions.

On several occasions when room temperature rose above $35^{\circ} \mathrm{C}$ individuals died apparently because this temperature exceeded the range of their temperature tolerance. During the winter months when aquaria were left on the uninsulated floor, water temperatures dropped below $10^{\circ} \mathrm{C}$ and the animals showed no 111 effects.

\section{Physical Invironment of the Hracinth Ponds}

The physical conditions of the water of the hjacinth ponds considered to be important in the resplration of Pseudobranchus were temperature, dissolved oxpgen and carbon dioxide contents, and pH. Measurements of these factors were made in the open water of the ponds and in water under the hyacinth mats in order to compare these two habitats.

Temperature measurements were taken in degrees centigrade at six inch depths with a spencer thermometer. Water samples for oxggen and carbon dioxide determinations 
were taken at six inch depths in ground glass stoppered bottles. The determination of oxggen was by the Winkler method and free carbon dioxide analysis was done by titration with $\mathbb{N} / 44$ sodium hydroxide with phenolphthalein as an indicator (Welch, 1948). The $\mathrm{pH}$ of the water was determined with a Beckman Model N portable pH meter and with pHydrion test paper.

\section{Aquatic Respiration and Temperature}

Two procedures of oxygen determinations that have been used for measuring aquatic respiratory rates in amphibians are the chemical Winkler method and the manometric Van Slyke method. Helff (1927) used the Winkler method in a comparative study of several Ambystoma larvae. The Winkler method was used by Btkin (1934) to determine the respiratory rates of bullerog tadpoles. Bvans (1939) used the Winkler method for the aquatic tests in comparing consumptions of several plethodontid salamanders. Vernberg (1952 and 1955a) employed the Van Slyke method of oxygen determination for his studies of the respiration of several plethodontids. A critical analysis of the Winkler method was made by Allee and Oesting (1934). Both Oesting (1934) and Wilder (1937) found no significant differences in the results obtained from the methods of Winkler and Van Slyke in oxygen determination. 
For reasons of simplicity of equipment and reasonable simplicity of procedure the Winkler method was chosen for determining aquatic oxygen consumption of Psoudobranchus. Deviations from the Winkler technique as described by Welch (op. c1t.) were that the volumes of the water samples were $25 \mathrm{cc}$; the volumes of the reagents manganous sulfate, potassium hydroxide-potassium 1odide, and sulfuric acid were $0.1 \mathrm{cc}$ each; and the aliquots for titration were $20 \mathrm{cc}$. The aquatic respiratory rates of five adult female Psoudobranchus, varying in weight erom 3.0 grams to 4.5 grams, were measured at $15^{\circ} \mathrm{C}, 20^{\circ} \mathrm{C}$ and $25^{\circ} \mathrm{C} \pm 1^{\circ} \mathrm{C}$. The animals were run in succession at each temperature for a total of 15 trials in the experiment.

Bach Pseudobranchus was starved for 24 hours and placed in a round battery jar aquarium containing $2075 \mathrm{cc}$ of spring water. The animals was left for one-half hour and then transferred to a second aquarium containing an equal amount of water. This procedure was used to inoculate the first or control aquarium with bacteria that might contribute to the oxpgen utilization in the aquarium contalning the Pseudobranchus.

The Pseudobranchus was retained below the surface of the water by a circular plece of plastic-coated window screening. A similar piece of screening was placed in the control aquarium. Glass siphons were installed in both 
aquaria and the surfaces were covered with $2.5 \mathrm{~cm}$ of heavg mineral oil. Allee and Oesting (op. cit.) reported no oxggen contamination in water of low oxpgen content over a 24 hour period when the surface was covered with two to five centimeters of mineral oil.

Water samples were siphoned from both aquaria into $25 \mathrm{cc}$ bottles allowing them to overflow twlce the contents of the bottles. OxJgen determinations were made in terms of parts per million. The aquaria were placed in a water bath and maintalned at the desired test temperature. After ifve hours oxpgen determinations were again made and the differences from the first determinations were recorded. The mineral oil was siphoned from the aquarium containing the Pseudobranchus and the animal was removed and weighed. The differences between the determinations of the aquaria was converted to cubic millimeters of oxygen per gram per hour at standard temperature and pressure using the method of conversion as described by Welch (op. cit.).

\section{Effects of Carbon Dioxide and Oxygen}

on Respiratory Behavior

The following procedures were used to subject experimental animals to different tensions of carbon dioxdde and oxpgen in order to observe the effects of these gases on 
respiratory behavior. Filtered pond water was boiled for 15 minutes in a $2000 \mathrm{ml}$ Exlenmeger Plask to rid it of dissolved gases. The flask was sealed and allowed to cool to room temperature. After the water had cooled the Plask was opened and a slphon was installed to remove water samples for carbon dioxide and oxygen determinations. The bolling of the water lowered the contents of both gases to one part per million $\left(10^{-3} \mathrm{ml} / 1\right.$ ter $)$ or less.

The Pseudobranchus to be observed was placed in the flask. The patterns of respiratory behavior of the animals were subjectively determined to be of three categories. The first was that in which supplemental aerial respiration, characterlzed by frequent surfacing by the Pseudobranchus to gulp alr was used in addition to aquatic respiration. In the second type the animal rarely surfaced and aquatic respiration through the skin and expanded gills was sufficient. The third category was also aquatic but in this case the gills were constricted and therefore only integumentary gas exchange was emplojed.

Five Pseudobranchus were observed singly and in groups of two. When the patterns of respiratory behavior of the animals was stable enough for such behavior to be placed in one of the three mentioned categories carbon dioxide and oxggen determinations were made of the water in the Plasks. 
The tensions of the gases in the llask were changed by the addition of more water to the rlask and by bubbling the gases directly into the llask. The carbon dioxide source was a hydrochloric acld-sodium carbonate generator. The evolved gas was bubbled through a wash bottle before it was added to the water in the flask. The oxpgen source was air pumped into the water by means of a New Rochelle Cosmic Piston Pump.

\section{Erythrocyte Count}

The number of red blood cells per cublc millimeter of blood in Pseudobranchus was determined by standard techniques using a Spencer Bright Iine hemacjtometer. Five-hundredths of a milliliter of 1:1000 heparin was introduced Into the body cavity of each Pseudobranchus one hour before it was etherized and the blood was drawn from the heart into the diluting pipette. Five counts were made on each of five adult animals and the average of each set was taken as the exythrocyte count of each individual.

\section{Erythrocyte Size}

Measurements of the sizes of the exythrocytes were made by means of an American Optical micrometer. Samples 
of the blood from the above five pseudobranchus were used. Iengths and widths of 20 cells of each animal were measured in micra.

\section{Hemoglobin Value}

Grams of hemoglobin per $100 \mathrm{cc}$ of blood of PBeudobranchus were determined by the acid hematin test (Cohen and Smith, 1919) using a Bausch and Lomb Spectronic 20 colorimeter.

Pseudobranchus blood clots rapidly so each animal was infected with 0.05 ml of 1:1000 heparin one hour before it was etherized and the sample of blood was withdrawn. Each animal was elther used 48 hours after it was captured or had been kept well fed under laboratory conditions for one to four weeks. After the specimen had been etherized the body fluid was withdrawn from a small puncture in 1ts belly and then $20 \mathrm{cu}$ mm of blood was withdrawn directly from the heart into a Sahll blood pipette. The blood was hemolyzed in $5.0 \mathrm{ml}$ of 2 per cent hydrochloric acid and the hemolyzed red blood cells were allowed to settle for 5 hours. Thus they would not interfere with the colorimeter readings of the acid hematin solution. Readings were converted to grams of hemoglobin per $100 \mathrm{cc}$ of blood using the handbook of methods and callbrations of the spectronic 20 colorimeter. 


\section{RaSULTS}

\section{Physical Conditions of Pralrie Ponds}

The mats of floating water hyacinths affect the water temperature, dissolved oxpgen, free carbon dioxide, and to a lesser extent the $\mathrm{pH}$ of the water of the prairie ponds.

The accelerated vegetative growth and flowering of Bichornia coincided with the rising temperature in April and May in the Gainesville area. Alr temperatures and water temperatures at $81 \mathrm{X}-1 \mathrm{nch}$ depths were taken at 11 A.M. during this period and are recorded in Table 1. Figure 1 represents these readings.

The differences between the temperatures of the open water and the sub-hyacinth water increased during the period of the investigation. The water level dropped until the hyacinth mats were stranded on the mud bottom. This drop in water level could have been due to a lowering of the water table because of insufficient rainfall or to dredging and draining operations in conjunction with the construction of Interstate 75 across Payne's Prairie. 


\section{TABLE 1}

TEMPERATURE READINGS OF HYACINTH PONDS

\begin{tabular}{ccccc}
\hline & $\begin{array}{c}\text { Air } \\
\text { Date }\end{array}$ & $\begin{array}{c}\text { Open Water Sub-Hyacinth } \\
\text { Temperature }\end{array}$ & $\begin{array}{c}\text { Difemperature } \\
\text { Temperature } \\
\text { Open-Byacinth }\end{array}$ \\
\hline $4-12-63$ & $28^{\circ} \mathrm{C}$ & $23^{\circ} \mathrm{C}$ & $22.5^{\circ} \mathrm{C}$ & $0.5^{\circ} \mathrm{C}$ \\
$4-16-63$ & $26^{\circ} \mathrm{C}$ & $25^{\circ} \mathrm{C}$ & $22^{\circ} \mathrm{C}$ & $3.0^{\circ} \mathrm{C}$ \\
$4-18-63$ & $28^{\circ} \mathrm{C}$ & $24^{\circ} \mathrm{C}$ & $20^{\circ} \mathrm{C}$ & $4.0^{\circ} \mathrm{C}$ \\
$5-1-63$ & $26^{\circ} \mathrm{C}$ & $30^{\circ} \mathrm{C}$ & $23^{\circ} \mathrm{C}$ & $7.0^{\circ} \mathrm{C}$ \\
$5-18-63$ & $33^{\circ} \mathrm{C}$ & $35^{\circ} \mathrm{C}$ & $26^{\circ} \mathrm{C}$ & $9.0^{\circ} \mathrm{C}$ \\
$5-22-63$ & $29.5^{\circ} \mathrm{C}$ & $35^{\circ} \mathrm{C}$ & $24^{\circ} \mathrm{C}$ & $11.0^{\circ} \mathrm{C}$ \\
\hline
\end{tabular}


21

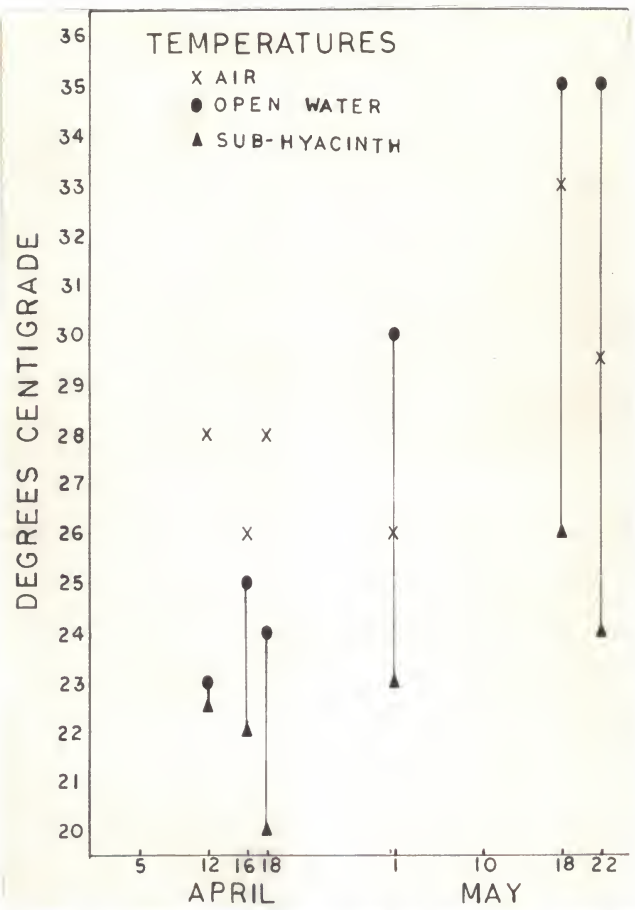

F1g. 1.-Temperature readings of the air, open water, and sub-hyacinth water of a prairie pond during April and May of 1963. 
The shading effect of the hyacinth mat and the subsequent drop in photosynthetic activity of phytoplankton and rooted vegetation under the mat produced the expected inverse oxggen-carbon dioxide relationship in water under the hyacinths as compared with the open water. The oxygen content of the water was lower under the hyacinth than in the open water and at the same time the carbon dioxdde content is higher. The relationships are graphed in Figure 2.

\section{Aquatic Respiration and Temperature}

As shown in Tables 2, 3, and 4, the mean oxygen consumption of the five Pseudobranchus tested at $15^{\circ} \mathrm{C}$ was $19.88 \mathrm{~mm}^{3} / \mathrm{gm} / \mathrm{hr}$, at $20^{\circ} \mathrm{C}$ the mean was $29.92 \mathrm{~mm}^{3} / \mathrm{gm} / \mathrm{hr}$, and at $25^{\circ} \mathrm{C}$ the mean was $37.76 \mathrm{~mm}^{3} / \mathrm{gm} / \mathrm{hr}$. A Q 10 value of 1.98 was determined in this range.

\section{Effects of Carbon Dloxide and Oxygen Concentrations on Respiratory Behavior}

The observed differences in respiratory behavior at various carbon dioxide and oxpgen tensions are recorded in Figure 3. A poljgon enclosing the symbols for aquatic respiration with expanded gills encompasses only one symbol for another type of respiratory behavior. 


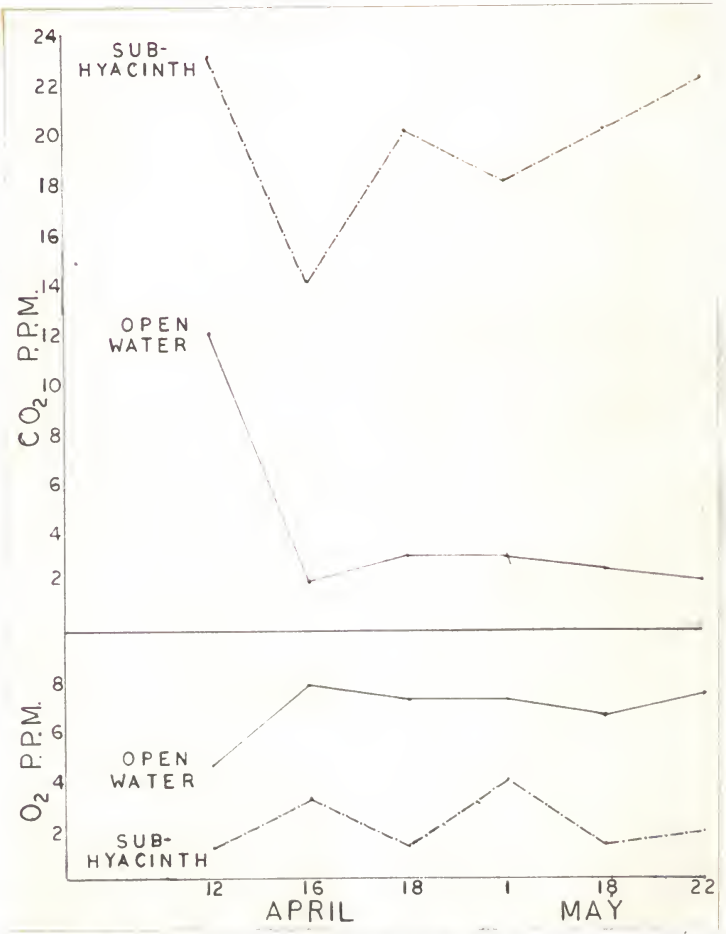

Fig. 2.-0xygen and carbon dioxdde concentrations in open water and sub-hyacinth water in April and May of 1963. 


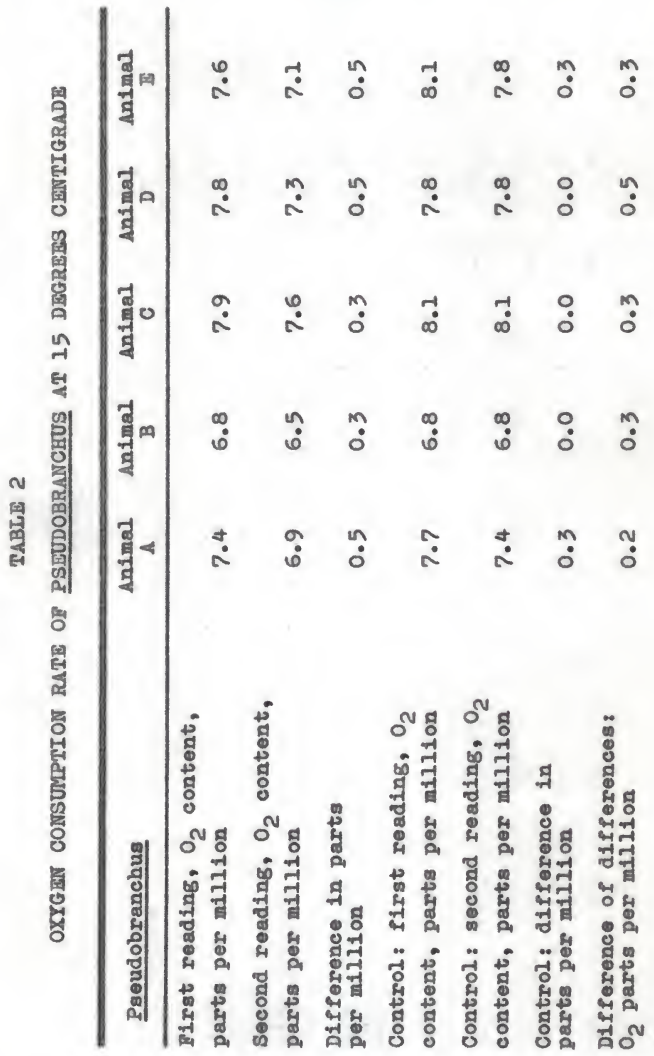




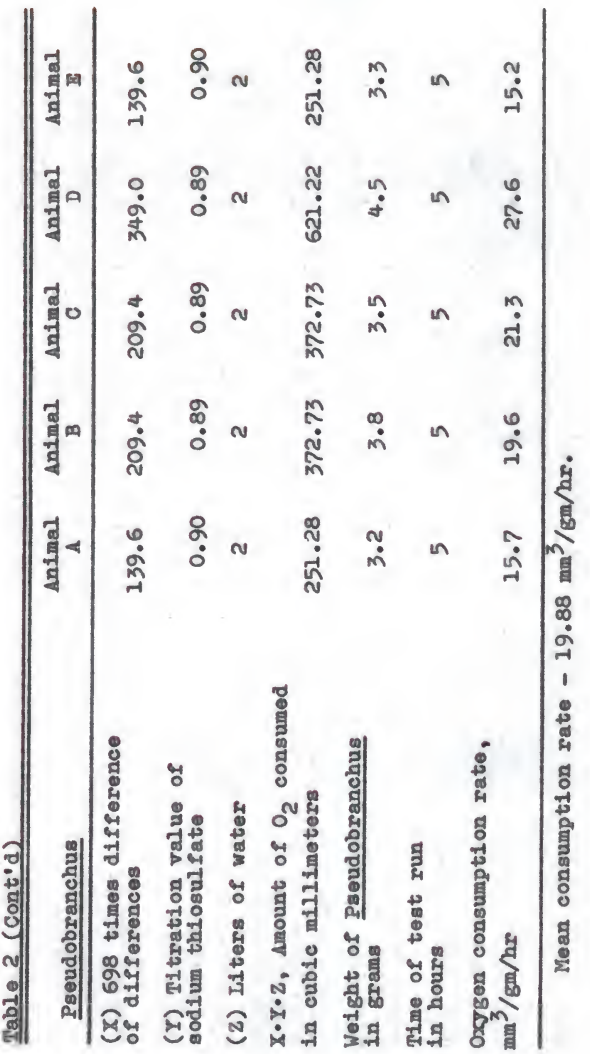




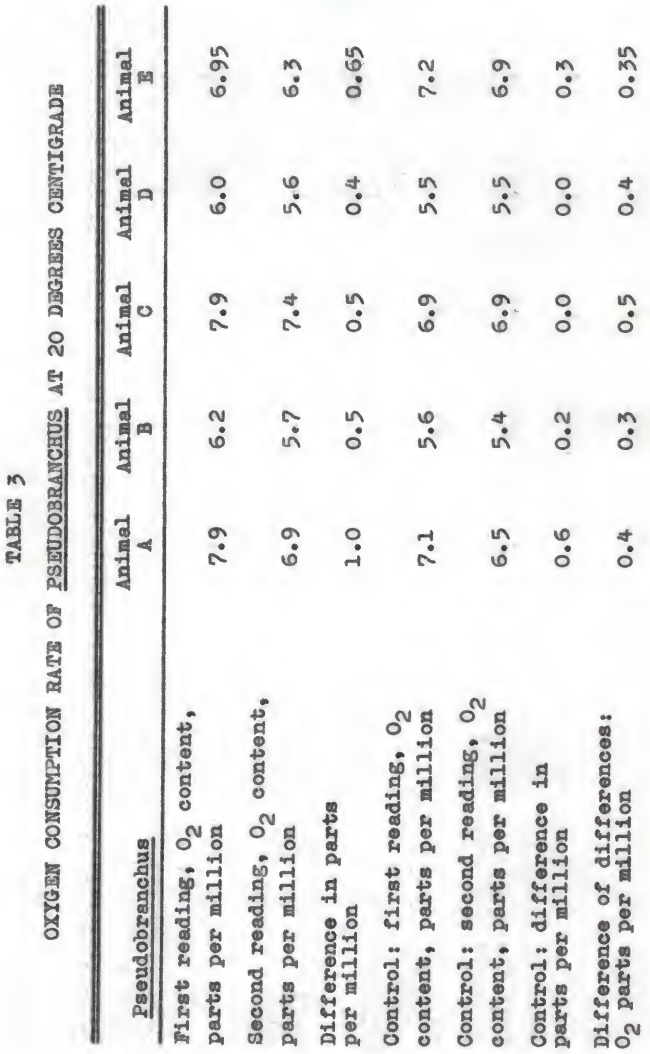




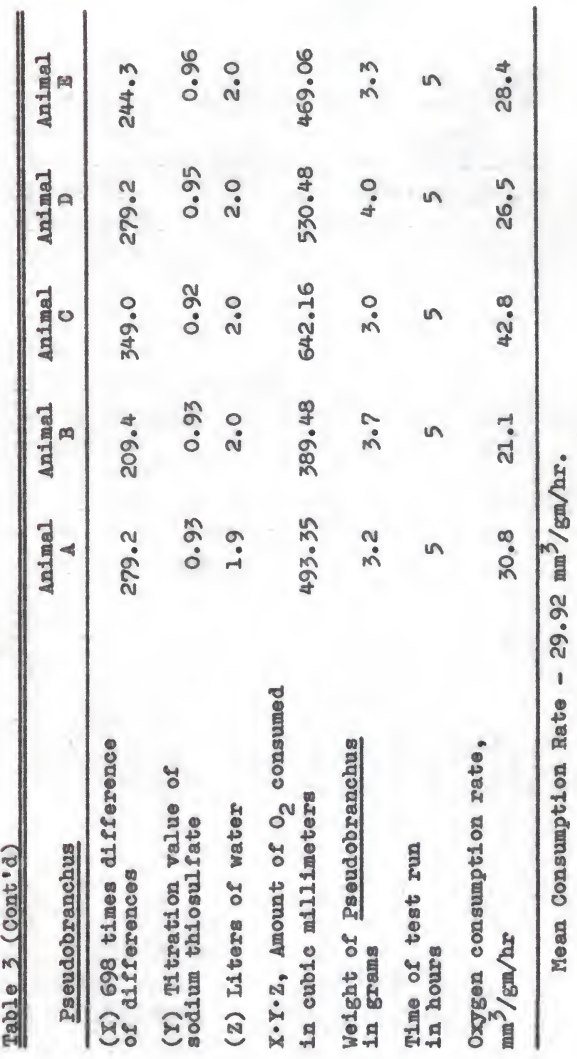




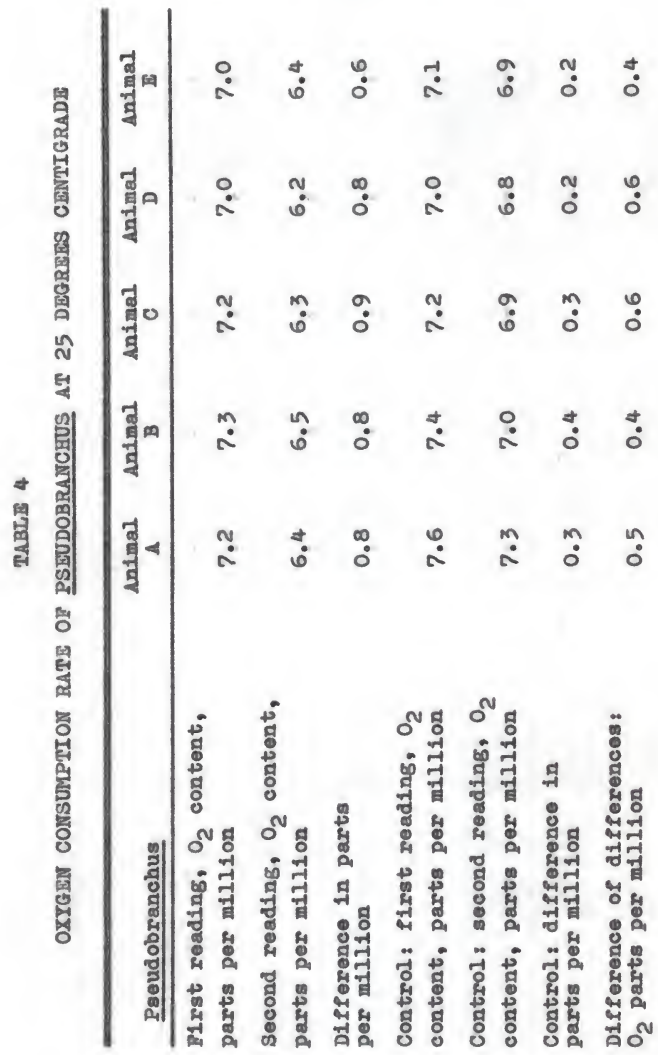




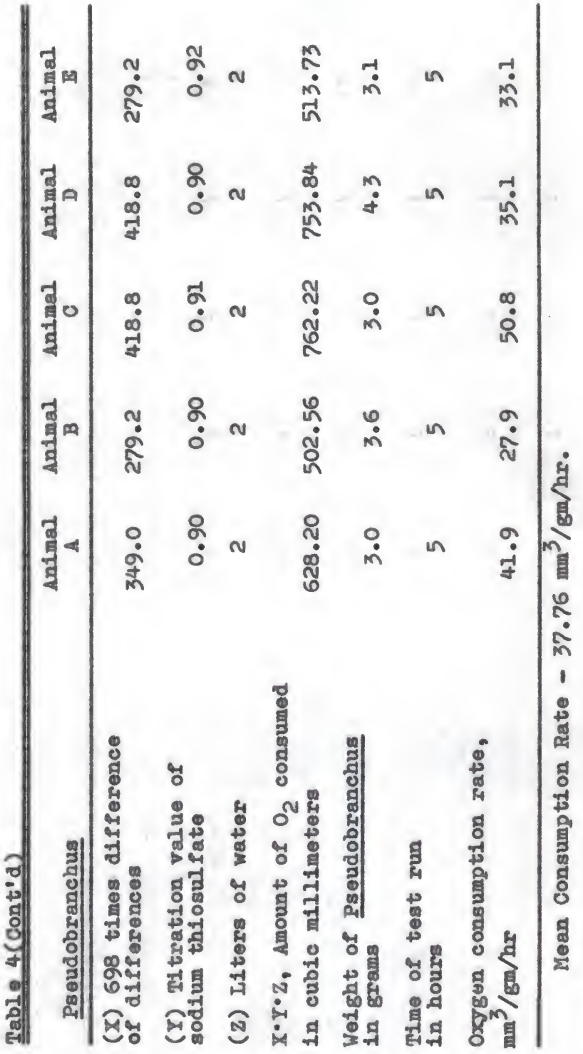




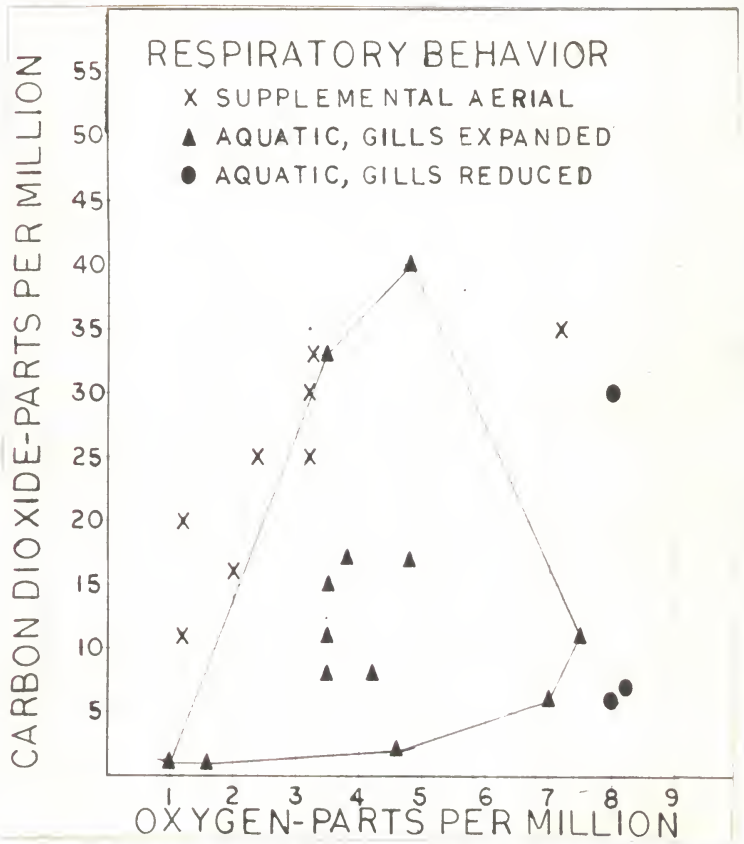

Fig. 3.-Respiratory behavior of Pseudobranchus at different concentrations of oxggen and carbondioxide. 


\section{Brythrocyte Count}

The exythrocyte counts of five adult Pseudobranchus were $74000,86000,88000,90000$, and 92000 cells per cuble millimeter of blood with a mean of $86000 \mathrm{cells} / \mathrm{mm}^{3}$ and with a standard deviation of 7050 .

\section{Erythrocyte S1ze}

The mean length of 100 red blood cells was 48.1 micra with a standard deviation of 1.36 micra and a coefficient of variation of 2.8 per cent. The mean width was 23.4 micra with a standard deviation of 0.73 micra and a coefficient of variation of 3.1 per cent. The product of the length times the width in the oval red blood cells of Amphiblans while not giving the surface area of such cells does give a relative amount of surface if this value is calculated for all investigated species. The product of the mean length times the mean width in Pseudobranchus was 1125.5 . The length/width ratio was 2.05 .

The largest individual red blood cell measured 55.9 micra by 29.3 micra with a length times width value of 1637.9. The smallest red blood cell measured $34.5 \mathrm{micra}$ by 20.7 micra with a length times width value of 714.2 . The extremes of length/wiath ratio were 1.5 and 3.0 . The 
longest red blood cell was 62.8 micra and the shortest was 34.5 micra. The broadest red blood cell was 29.3 micra and the narrowest was 17.9 micra. These values represent a great range both in size and shape of the erythrocjtes In Psoudobranchus, but a graph (Fig. 4) of the ranges, means, two standard deviations, and four standard errors helps to show the rather low coefficient of variation.

\section{Hemoglobin Value}

The hemoglobin values for eight adult Pseudobranchus were $3.8,5.4,5.8,6.9,7.2,7.4,7.6$, and 10.2 grams per $100 \mathrm{cc}$ of blood. These give a mean of 6.8 grams of hemoglobin per $100 \mathrm{cc}$ of blood with a standard deviation of 1.76 and a standard error of 0.622 . A coefficlent of variation of 25.9 per cent was calculated for these determinations. 


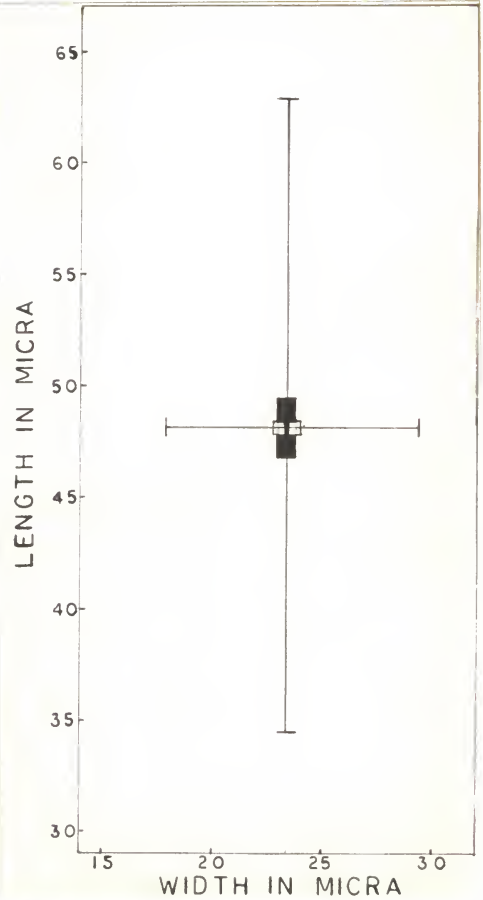

F1g. 4.-Prythrocyte size in Pseudobranchus. Vertical and horizontal lines Ind lcate ranges of length and width; crossing of lines indicates means; one black and one white rectangle combined on each slde of the mean, one standard deviation; white rectangle on vertical and bleck rectangle on horizontal, two standard errors. 


\section{DISCUSSION}

\section{Physical Conditions of Hyacinth Ponds}

Payne's Prairie has had a history of fluctuating water levels which have varied this environment from that of a lake covering the entire basin to the relatively dry prairie with scattered hyacinth ponds of the present. The ponds could thus be considered semi-isolated remnants of a shallow dystrophic lake. Their water levels fluctuate greatly between drought perlods and the heavy ralny seasons, with many ponds going completely dry at times. At other times the ponds may overflow their sometimes 111-defined banks and coalesce through shallow stretches of flooded prairle with nelghboring ponds often of considerable distances away.

Such fluctuations in water level place limitations on the types of organisms that could successfully survive in the hracinth pond habitat on a long term basis. The pond species could be divided into four categories, those whose individuals had moved into the pond during flood stages from other ponds, those that could move overland from other ponds, those that had survived by being able to 
estivate for short periods, or those that pass through an extended dormancy over dry periods. Pseudobranchus seems to most often survive in any one pond by estivating during dry periods.

The hyacinth mats contribute to the lowering of the volume of water in the ponds by the accumulation on the bottom of the ponds of detritus from the floating plants. The hyacinth mats amellorate living conditions for some aquatic animals. The modifying effect of the floating mats of vegetation keeps the sub-hyacinth water cooler than the open water, especially at low water levels, and no doubt enables some ectotherms to survive when otherwlse they could not without the protection of their heat reflecting canopy of hyacinths. Body temperatures of aquatic salamanders usually are identical with the water temperature in which they are found. Brattstrom (1963) reports that some aquatic salamanders appear to select specific temperature regions or levels within ponds. His September, 1954 record for collecting Pseudobranchus from Payne's Prairie gave the temperature of the water at $24^{\circ} \mathrm{C}$. The $35^{\circ} \mathrm{C}$ temperature reached in the open pond water is in the range of the critical thermal maxima of many salamanders (Butchison, 1961) and could be avoided by Pseudobranchus by selecting the cooler water under the hyacinths. If the water levels of the ponds drop enough for the hyacinth mats to be 
stranded their matted fibrous roots retain molsture more efficiently than mere muckg sand and such animals as Siren, Pseudobranchus, Seminatrlx, annelids, water beetles, etc. are afforded a refuge that may retard their rates of desiccation when the ponds go dry.

The rather peculiarly spaced dates for the gathering of the data at the ponds were selected because of the meterological changes that took place in the area just previous to the time of the readings. Climatological data from the Gainesville area for the months of April and Maj, 1963 are shown in Tables 5 and 6. The Beef Research Unit (BRU) is nearer Payno's Prairle than the orficial U. S. Weather Bureav station. The data of the temperatures in the prairle pond reflect the changes in the temperature recorded officially at the Beef Research Unit.

A general description of the weather in the pond area in the month of April, 1963 would be "falr and warm," but a cold front moved through the area during the middle of the month and the minimum temperature was $25^{\circ} \mathrm{I}$ lower on April 16 than on April 12. The air temperature at the pond dropped at that time (Fig. 1) and though the water temperature had dropped further on April 18, the air temperature on the 18th was higher than on the 16th. On both May 1 and May 21 heary rain fell at the pond and the Beef Research Unit. The climatological data from the U. S. Weather Bureau for those 


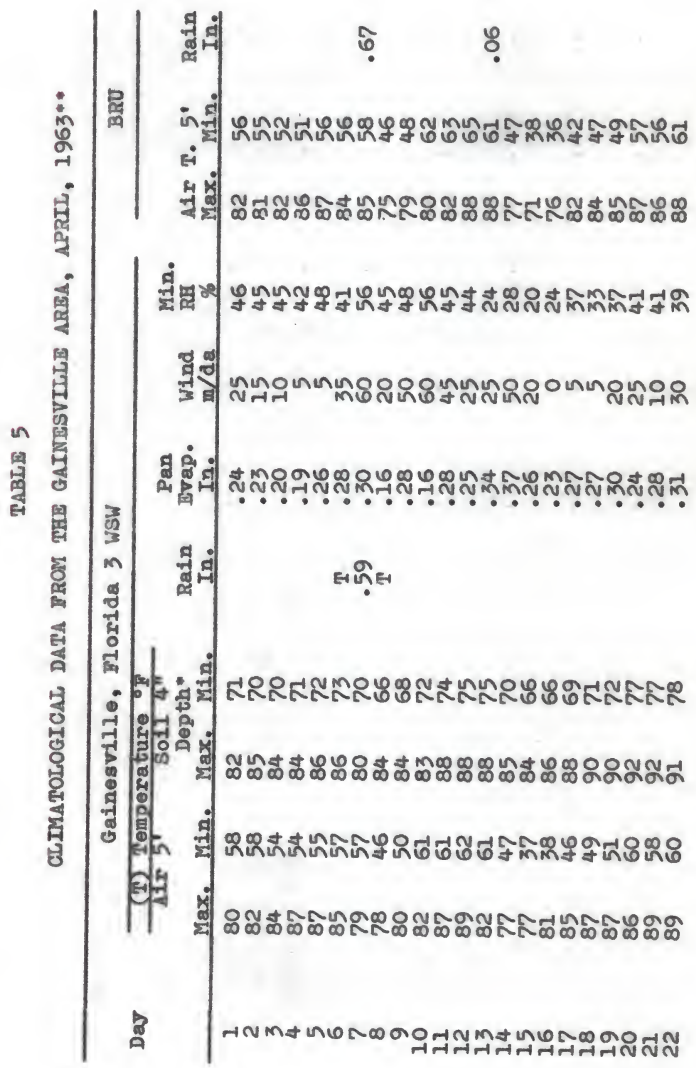




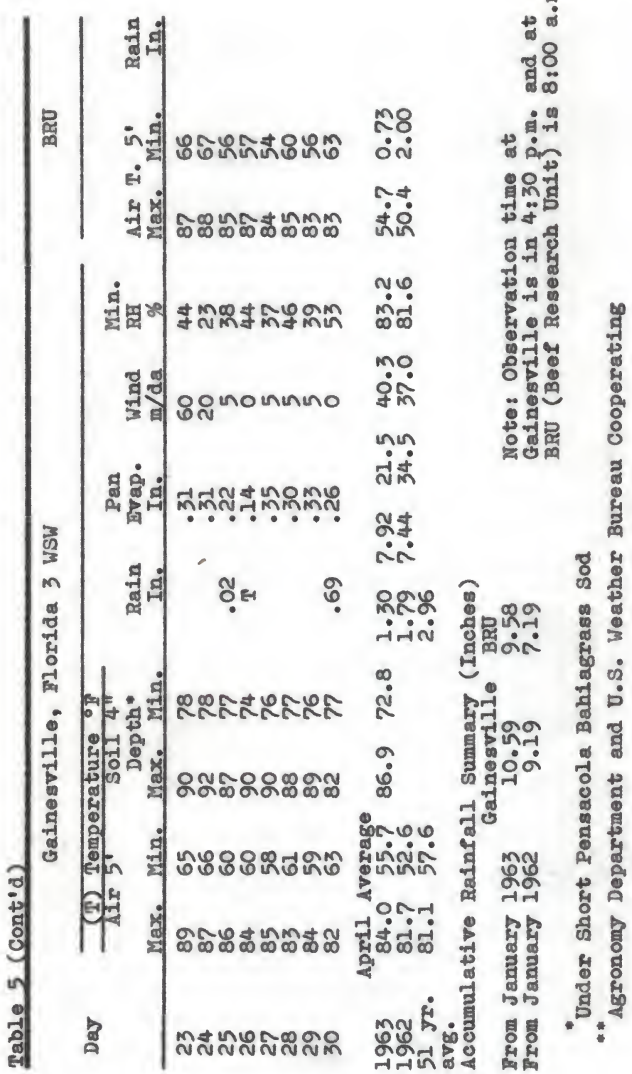




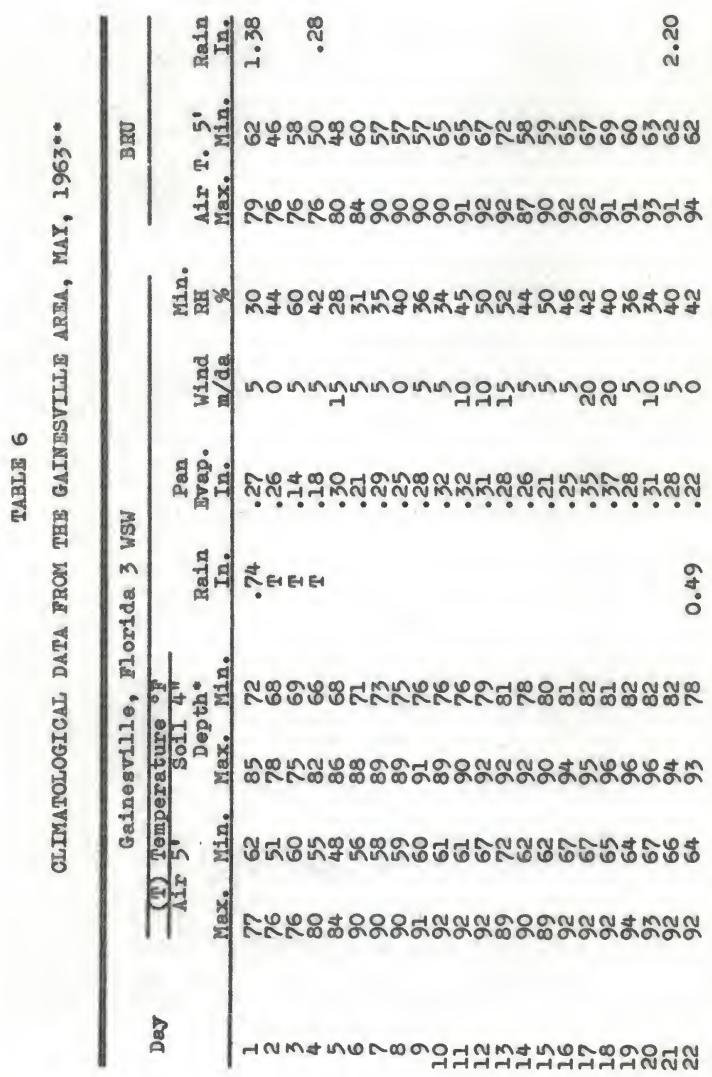




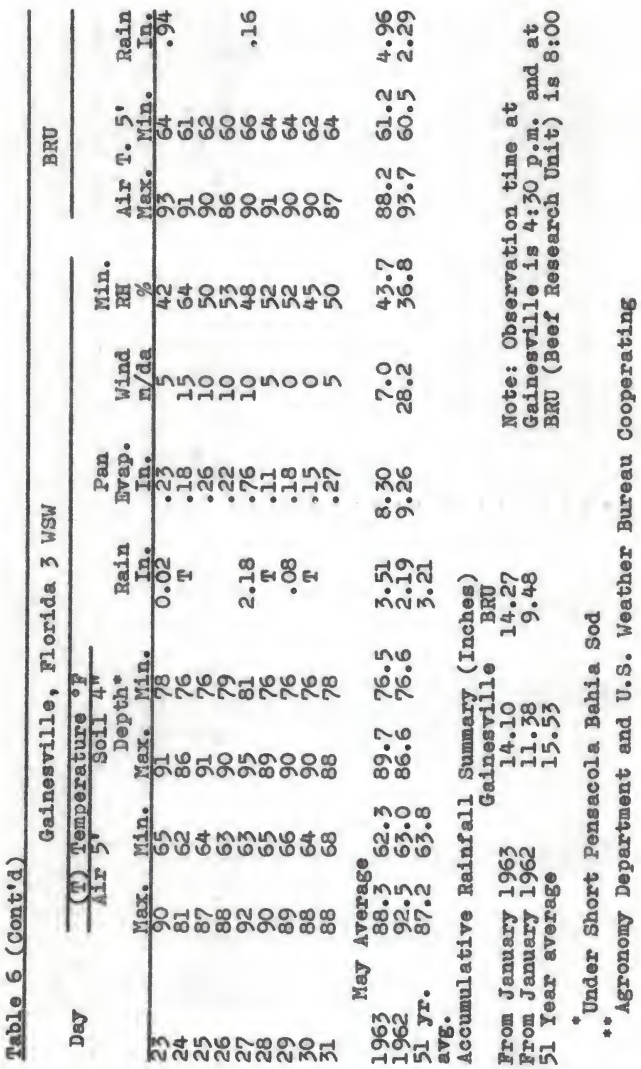


two dates indicate the differences in the causes for the precipitation. The lower temperatures after May 1 show the effects of a cold front. The high temperature of the latter part of May show that precipitation on the 2lst was from an isolated thunderstorm. On both May 1 and May 22 the temperature of the open water was well above that of the alr temperature by the time of the readings. These data indicate that though shower activity may cool off the air at the ponds the higher solar energy warms up the ghallow open water of the ponds very rapidly. By May 22 the deepest part of the pond was only six inches. At this date the difference in the temperature of the open water and the water under the hyacinths was $11^{\circ} \mathrm{C}$.

The lower oxygen and higher carbon dioxide contents of the water under the hjacinths could place respiratory stress on animals restricted to aquatic respiration. Pseudobranchus, with its ability to utilize lungs as well as skin and gills, is not so affected. Even though the oxpgen content of the water underneath the hyacinths may drop to below two parts per million the Pseudobranchus is not in respiratory difficulty for it can rise to the surface and gulp air. The lack of oxjgen in the sub-hyacinth water poses no problem and the cooler temperature is an asset to an ectothermic amphibian. 
Though the carbon dioxide content of the water under the hyacinths is higher than that of the open water there does not seem to be a significantly lower pH of the water under the hyacinths. As the pond waters dropped several large limestone boulders were revealed which could possibly contribute a buffering effect to the water of the pond.

\section{Oxgren Consumption and Temperature}

The respiratory rate of Pseudobranchus is relatively low when compared with that of other amphiblans of approxtmately the same body welght. Wilder (1937) found the respiratory rate of Desmognathus fuscus at $20^{\circ} \mathrm{C}$ to be from 32.6 to $49.2 \mathrm{~mm}^{3} / \mathrm{gm} / \mathrm{hr}$ and that for Burrces bislineate to be 55.7 to $89.9 \mathrm{~mm}^{3} / \mathrm{gm} / \mathrm{hr}$. Vernberg (1952) measured the rate of oxygen consumption at $10^{\circ} \mathrm{C}$ of Eurycea bislineata at 38 to $44 \mathrm{~mm} / \mathrm{gm} / \mathrm{hr}$ and of Plethodon cinereus at 30-37 $\mathrm{mm}^{3} / \mathrm{gm} / \mathrm{hr}$. At $20^{\circ} \mathrm{C}$ the rate of oxggen consumption of $\underline{P}$. cinereus was $50.63 \mathrm{~mm}^{3} / \mathrm{gm} / \mathrm{hr}$ while at the same temperature the rate for P. glutinosus was only $33.35 \mathrm{~mm}^{3} / \mathrm{gm} / \mathrm{hr}$ (Vernberg, 1955a). In all the above cases the investigators concluded that the differences in the respiratory rates at equal temperatures were due to the more active behavior of the salamanders with the higher rates. 
Pseudobranchus by such standards would be considered an amphibian of low activity rate. Though it does have brief periods of violent activity in eluding capture, for the most part it appears sluggish and quiet in aquaria. The waters of the prairio ponds or ditches are practically devold of any currents that would impose a stress on the swimming ability of Pseudobranchus. Therefore it would seem that the only stimuli for extreme activity in 1 ts normal environment would be in escape from its enemies or in brief struggles subduing and ingesting larger invertebrate prej.

A summary of the data on respiratory rates of Pseudobranchus in the $15^{\circ} \mathrm{C}-25^{\circ} \mathrm{C}$ temperature range is shown in Table 7. A two-way analysis of variance on this oxggen consumption data showed no significant differences among the five animals but significant differences $(P<.01)$ in oxggen consumptions at the different test temperatures. Since the temperatures were equally spaced, linear and quadratic components of the temperature response could be separated by orthogonal sub-division of the sum of squares. The method and coefficients were taken from Cochran and Cox (1957). This analysis (P1g. 5) showed that the response to temperature was linear in the temperature range of this experiment $\left(15^{\circ}-25^{\circ} \mathrm{C}\right)$. 


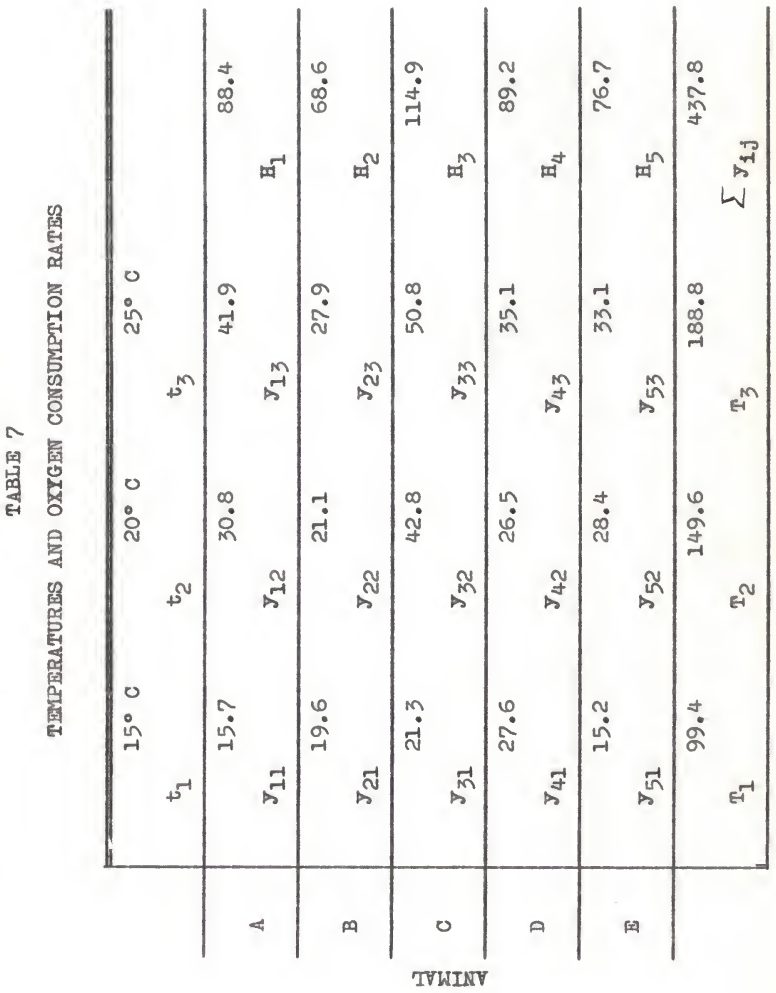




\section{ANALYSIS}

\begin{tabular}{lcccc}
\hline Sources & d.f. & S.S. & M.S. & V.R. (F) \\
\hline Animals & 4 & 409.43 & 102.36 & 3.11 \\
\hline Temperatures & 2 & 803.27 & 401.64 & $12.20 *$ \\
\hline Linear & 1 & 779.24 & 779.24 & $24.28 * *$ \\
\hline Quadratic & 1 & 4.03 & 4.03 & 0.12 \\
\hline Brror & 8 & 263.30 & 32.91 & \\
\hline Total & 14 & 1475.99 & & \\
\hline
\end{tabular}

ture.

Fig. 5.-Analysis of oxggen consumption and tempera- 
Fuhrman and Fuhrman (1959) found a linear relationship between oxggen consumption and temperature in the salamander Ensatina eschsoltzi1 at $15^{\circ}-22.8^{\circ} \mathrm{C}$.

$A Q_{10}$ value of 1.98 was calculated for oxpgen consumption of Pseudobranchus in the $15^{\circ}-25^{\circ} \mathrm{C}$ range. Apparently the $Q_{10}$ value of oxjgen consumption of caudate amphibians have not been calculated but the $Q_{10}$ value of oxggen consumption for Pseudobranchus does not seem significantly lower than expected for sluggish poikilotherms (Prosser, et al. 1950).

Though the temperatures of the air and open water In the ponds reach extremes out of the $15^{\circ}-25^{\circ} \mathrm{C}$ range the temperature range of the water under the hjacinth approximates that of the test. The hyacinth mat acts as a thermoregulating agent by reflecting the radiant heat of the sun during the day and as an insulating agent against re-radiation loss of heat at night. Thus under the moderating influence of the hracinth mat the temperature fluctuation of the environment are not so great as to overtax the resplratory capacity of the ectothermic Pseudobranchus. 
Effect of Oxygen and Carbon Dioxide on Respiratory Behavior

The primary respiratory stimulus of the terrestrial vertebrates is generally considered to be an increase in the partial pressure of carbon dioxide in the environment and subsequently in the animal's blood stream. Any respiratory stress is characteristically met in such animals by an increased rate of ventilation. In those aquatic vertebrates which have aerial means of respiration, stimulus and response usually are the same as in terrestrial animals. However, in most lower aquatic form, respiratory stimulation is more likely to be a result of low oxygen concentration in the water rather than high carbon dioxdde concentration and the response of most gilled vertebrates is either an expansion of gill surface area or an accelerated rate of movement of water over the gills (Prosser, et al. 1950).

Studies of the respiratory behavior of amphiblans under hlgh and low concentrations of oxpgen and carbon dioxide have for the most part failed to quantify the concentration of the gases at the time the respiratory behavior was noted. Drastich (1925) observed a greater development of the gills of larval Salamandra under low oxggen concentration than under high oxggen concentration. Noble (1927) attributed the proportionally large gills of 
the tadpoles of Hyla rosenbergi to the poor oxpgen supply in their breeding basing. He also states (Noble, 1931) that the larvae of both Siren and Pseudobranchus have the ability to reduce their gills if respiratory conditions are not sultable for g1ll functions. According to Brattstrom and Merarland (1955) specimens of the newt Tarlcha torose were so unresponsive to a rapid increase in carbon dioxide in their aquatic environment that they lost their motility and did not attempt to elther rise to the surface to gulp air or crawl out on rocks available to them. Savage (1952) suggests that low oxpgen tension does have some influence on the pulmonary system of anurans. He says the early development of lungs in the life history of the frog Rana temporaria is an important adaptation to 1ts life in ponds of low oxggen content.

Work of a quantitative nature on the respiration of an ectothermic vertebrate was done bj Willmer (1934). He invegtigated the influences of different tensions of oxygen and carbon dioxide on the jarrow Exythrinus exythrinus, a tropical fish of acid swamps, which respires by means of an alr blader as well as gills. During periods of aerial respiration the jarrow came to the surface at three to four minute intervals with its gill chambers remaining closed by Its opercula. Its gill chambers were open and the jarrow remalned below the surface during periods of aquatic 
respiration. Willmer also observed a third type of respiratory behavior which combined both aeriel and aquatic respiration which he considered intermediate to the other two.

Willmer determined experimentally that the jarrow was forced to rely on aerial respiration when the oxggen content of the water was below $0.5 \mathrm{cc}$ per 11 ter or when the carbon dioxide content of the water was either above $35 \mathrm{cc}$ per 11 ter or below $5 \mathrm{cc}$ per liter at a pH in the range of its natural swamp onvironment. As long as the dissolved oxggen was above $1.5 \mathrm{co}$ per liter, except when the carbon dioxide content was above 25 or $30 \mathrm{cc}$ per 11 ter or below $10 \mathrm{cc}$ per liter, the Jarrow was able to resplre entirely by aquatic means. At intermediate concentrations of oxjgen and carbon dioxide both aerial and aquatic respiration were emplojed.

Willmer explained forced aerial resplratory behavior with its permanently closed gill openings as a method of preventing the possible loss of oxpgen to the water through the gills. Similarly at high carbon dioxide concentrations the fish might be compelled to keep the gill chambers closed to aroid absorbing carbon dioxide from its environment. At least $5 \mathrm{cc}$ per liter of carbon dioxide was considered necessary to stimulate the jarrow to move its opercula and gills so below that level the fish was forced 
to come to the surface to get air. Thus Willmer considered the yarrow to be responsive to both oxygen and carbon doxide in its respiratory behavior.

Dehadrai (1962) ran experiments on the 11sh Notopterus similar to the ones done by Willmer on Brythrinus and the resplratory behavior of the two flshes was similar. Respiratory behavior in Notopterus is purely aerial when free carbon dioxide in the water is below 5 parts per million or above 60 parts per million at oxpgen concentrations Irom 1 to 8 parts per million. At carbon dioxide concentration of 10 to 40 parts per million and oxpgen from 2 to 8 parts per million the respiratory behavior of Notopterus was mainly aquatic. Between the conditions when either aquatic or aerial respiratory behavior was dominant there was a range in which the 11 sh resorted to "intermediate respiration."

The phases of respiratory behavior in Pseudobranchus were not as easily delinited as in Exythrinus or Notopterus. Pseudobranchus obviously does not have an operculum to be used as an indication of change from aquatic to aerial means of respiration. The constriction of the external gills is not so obvious as to give a hairline demarcation in any individual between supplemental gill usage and rellance on skin surface alone. However, the data graphed in Figure 3 show a definite enough influence of oxggen and 
carbon dioxide on respiratory behavior to warrant hypotheses on this relationship.

Brattstrom and McFarland (ㅇp. c1t.) attribute the failure of carbon dioxide to stimulate respiration in Taricha to the fact that the gas does not accumulate in very high concentrations in its natural environment. This is not the case, of course, for Pseudobranchus, as the concentration of carbon dioxide may get quite high under the hyacinth mats in the prairie ponds due to the respiration of the sub-hyacinth plants and animals and the reduced rate of photosynthesis due to lack of sunlight. The effect of high carbon dioxide concentration of the water in which Pseudobranchus is found is one of stimulating pulmonary ventilation. This effect is most evident when oxygen tension 1s low, again the condition under the hyacinths. The utilization of the lungs in some perennibranchs has been questioned on the basis of anatomy or behavior. Luckhardt and Carlson (1920) conclude that Necturus does not use its lungs for respiration. Noble (1931) mentions the poorly vascularized lungs and lack of alveoll in some newts and In the perennibranchs Proteus and Necturus. Krogh (ㅇp. cit.) shows diagrams of the lungs of Siren having simple septa as opposed to the smooth surfaces of the lungs of Proteus. Hilton (1952) describes the lungs of Siren as "quite simple sacs" but he remarked that the close 
network of capillaries in the lungs indicated their respiratory function. Czopek (1962) found that in Siren intermedia the lung capillaries represent 61 per cent of the total capillaries of the respiratory organs. His study also showed the skin capillaries to be 36 per cent, the gills to be 2 per cent, and the mouth cavity to be 1 per cent of the resplratory surface. Whitford and Hutchison (1963) say that the lungs and buccopharyngeal mucosa of Ambystoma maculatum become more important as respiratory structures at temperatures above $15^{\circ} \mathrm{C}$. The lungs of Pseudobranchus are anatomically and histologically similar to those of Siren and from the behavior of the animals under the influence of carbon dioxide are obvlously 1mportant respiratory organs.

Pseudobranchus can survive on pulmonary respiration alone. I placed an adult Individual into an Erlenmejer flask containing 1500 milliliters of bolled spring water and covered the surface with mineral oll. After depleting the oxsgen concentration of the water to a point below 0.5 parts million and raising the carbon dioxide concentration to 5 parts per million, the Pseudobranchus was able to survive for 72 hours by surfacing for air about seven times per hour. Unfortunately the animal also engulfed a fair amount of mineral oil during this period and had to be removed from the flask. A Juventle $(75 \mathrm{~mm})$ Pseudobranchus 
lived for six days in a $250 \mathrm{ml}$ beaker containing mineral oll one centimeter deep and no water. It was unable to swim in the oil but could Plex its body enough to get its mouth above the surface to breathe. After it was returned to an aquarium it swam normaliy and within 15 minutes fed on an earthworm.

The size of gills in Pseudobranchus seems to be influenced by the oxpgen content of the water. Though not shown in Figure 3, at lower oxpgen concentration the gills are larger. Figures 6 and 7 show the gills of an individual at oxpgen concentration of 7.7 and 2.8 parts per million, respectively. The gills of a Pseudobranchus may expand to a relatively tremendous size if the animal is exposed to a very low concentration of oxygen for an extended period. Figures 8 and 9 show an animal that had been retained below the surface of oll-coated water in which Its aquatic respiration had reduced the oxggen content from 6.8 parts per million to 1 ess than 1 part per million in a 24 hour period. The Pseudobranchus was motionless apparently because of hypoxia for 1 t again became active after one hour In fresh spring water after frequent proddings with a dissecting needle. Dehadrai (op. cit.) reported similar restoration to normal activity of asphyxiated Notopterus in fresh water. He was even able to practice "artiflcial 


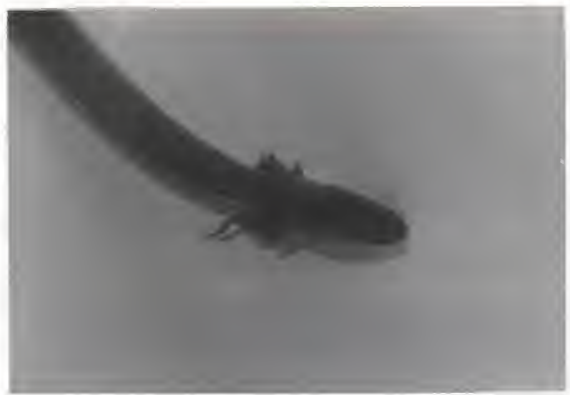

P1g. 6.-Pgeudobranchus in water with oxggen concentration of 7.7 parts per million.

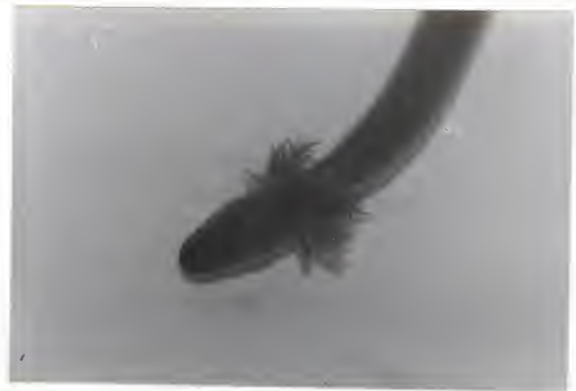

Fig: 7.-Same antmal in water with oxggen concentration of 2.8 parts per million. 


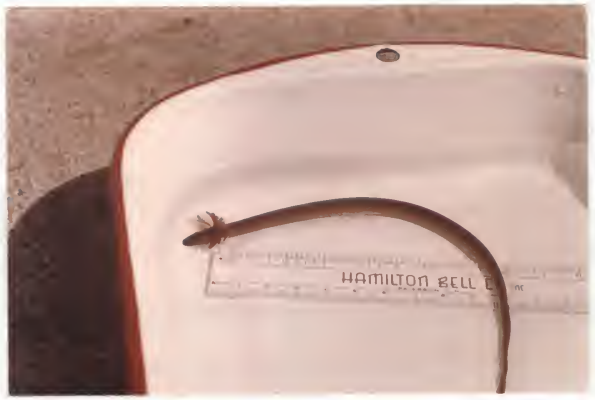

Fig. 8.-Pseudobranchus after prolonged retention in water of oxgoen concentration of less than one part per million.

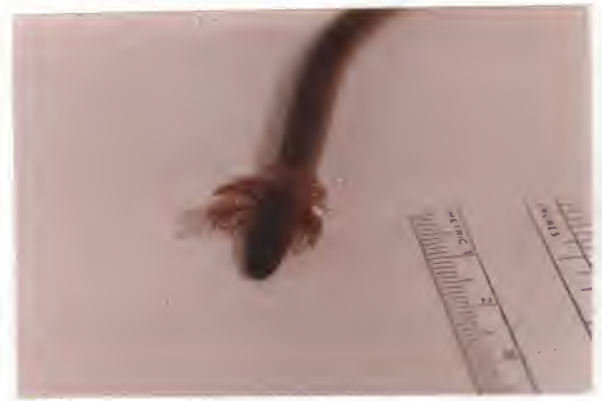

Pig. 9.-Same animal, enlarged view. 
respiration" on such fish by infecting fresh air into its empty swimbladder by means of a hypodermic syringe.

Other factors affecting gill size are food and activity. After leeding, Pseudobranchus usually goes through a period of little activity in which its gills often increase in size, probably due to the increased metabolic activity of the digestive processes. After perlods of agitation characterized by rapid and prolonged swimming by the Pseudobranchus its gills also expand. In this case probably the reason is because of the oxpgen debt built up during the activity of the animal.

However, fills are at best respiratory conveniences because the animals can live without them. Those animals taken from the burrow habltats have no gills and when they are placed in water they may take up to three weeks to grow new ones. Goin (1941) removed the gills from several Pseudobranchus and placed the animals in aquaria. He concluded from his observations that those animals which were allowed to come to the surface and gulp air for a period before being retained under the water were able to later survive on skin respiration alone. Those animals that were immediately retained underwater after their gills had been exc1sed d1d not survive. MeCrady (1954) removed the gill rami from the salamander Gyrinophilus palloucus and reported the animals died without their gills having regenerated. 
I removed the gills from four Pseudobranchus and put them into separate aquaria in which thej were screened from the surface. They went Into periods of bleeding and "shock" as described by Goin as well as a sloughing of their epldermis due to handing. After recovering from the "shock" conditions the animals were found to survive in spite of the fact that they were unable to reach the surface and utilize aerial breathing. The inltial oxggen concentration in the water was 6.8 parts per million which may have been higher than that used by Goin and enabled my animals to survive without aerial breathing. The amount of blood lost, which could have easily been a survival factor, was not measured in either case.

\section{Brythrocite Size and Count}

Amphibians have the largest erythrocytes of all the vertebrates. The largest known red blood cells with a mean of $61.8 \times 36.7$ micra have been described by Smlth (1925). Amphibians also have the lowest red blood cell counts of all the vertebrates.

Though the red blood cell sizes of many species of amphibians have been measured there have been relatively Pew species in which both cell size and cell number have been investigated. Table 8 gives the mean erythrocyte 
TABLE 8

BRYTHROCYTE COUNT IN AMPHIBIANS

\begin{tabular}{|c|c|c|}
\hline Species & Source & $\frac{\mathrm{RBC}}{1000 / \mathrm{mm}^{3}}$ \\
\hline ㅌy la arborea & Prosser, et al. , 1950 & 670 \\
\hline Rana esculenta & Prosser, et al. 1950 & 530 \\
\hline Rana temporarla & Prosser, et al. 1950 & 408 \\
\hline Bufo vulgaria & Prosser, et al. . 1950 & 380 \\
\hline Desmognathus monticola & Vernberg, 19550 & 197 \\
\hline Furrces 1ucifuga & Vernberg, 1955b & 178 \\
\hline Desmognathus ochrophaeus & Vernbers, $1955 \mathrm{~b}$ & 169 \\
\hline Triturus vulgaris & Prosser, et al. 1950 & 135 \\
\hline$\frac{\text { Desmognathus }}{\text { quadramaculatus }}$ & Vernberg, 1955b & 131 \\
\hline Triturus alpestris & Prosser, et al. 1950 & 110 \\
\hline Diemyctylus virldescens & Prosser, et al., 1950 & 103 \\
\hline Plethodon cinereus & Vernberg, 1955b & 91 \\
\hline Gyrinophilus danielsi & Vernberg, $1955 b$ & 88 \\
\hline Pseudobranchus striatus & Freeman, 1963 & 86 \\
\hline Ambystoma tigrinum & Vernberg, 1955b & 81 \\
\hline Furrees bislineata & Vernberg, $1955 \mathrm{~b}$ & 80 \\
\hline Siren lacertina & Freeman, 1963 & 68 \\
\hline Amphiuma means & Freeman, 1963 & 67 \\
\hline Salamandra maculata & Prosser, et al. 1950 & 57 \\
\hline Necturus maculosus & Claypole, 1896 & 56 \\
\hline Plethodon slutinosus & Vernberg, 1955b & 56 \\
\hline Salamandra atra & Prosser, et al., 1950 & 54 \\
\hline Ambrstoma maculatum & Vernberg, 1955b & 53 \\
\hline Mecturus maculosus & Harr1s, 1953 & 51 \\
\hline Proteus anguineus & Prosser, et al.., 1950 & 36 \\
\hline Necturus maculosus & Vernberg, 19550 & 28 \\
\hline
\end{tabular}


counts of 24 species of amphibians. The measurements of the red blood cell sizes of these specles are shown in Table 9 which includes the product of the mean length times the mean width. In Table 10 the values of the products of the red blood cell counts times the length times the width are arranged in descending order. These data are taken from Clajpole (1896), Prosser, et al (1950), Harris (1953), Vernberg (1955b), and my measurements in Pseudobranchus, Siren, and Amphiuma.

Several generalizations can be made from the data in these tables. One is that the smallest and most numerous cells are found in the anurans. A second is that the large aquatic forms have the largest cells. A third and discouraging observation is that the data from different investigators are quite inconsistent. The three series of measurements of the erythrocytes of Necturus maculosus vary greatly. Vernberg's (1955b) Necturus counts and measurements are so far below those of Claypole (1896) and Harris (1953) as to make questionable his data on the other salamanders as well. However, I measured the red blood cells of Desmognathus fuscus from the Gainesville area and found the mean size to be $31.4 \times 16$ micra, well within the ranges of the three species of Desmognathus measured by Vernberg. Since Vernberg's measurement of the erythrocyte width in Hecturus was the same as that recorded by Harris it would 


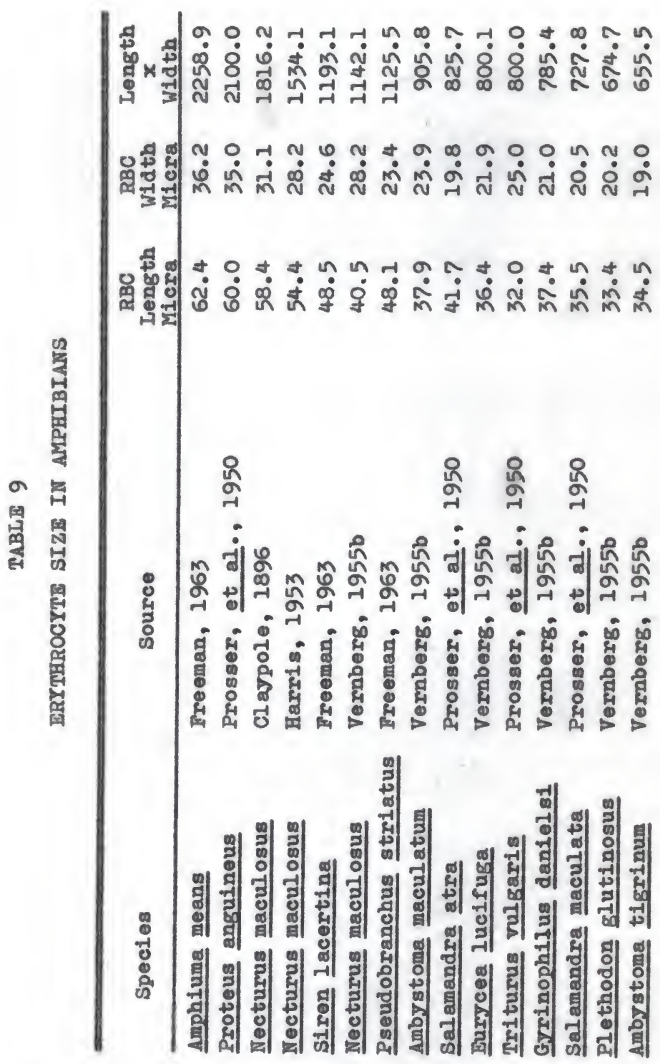


61

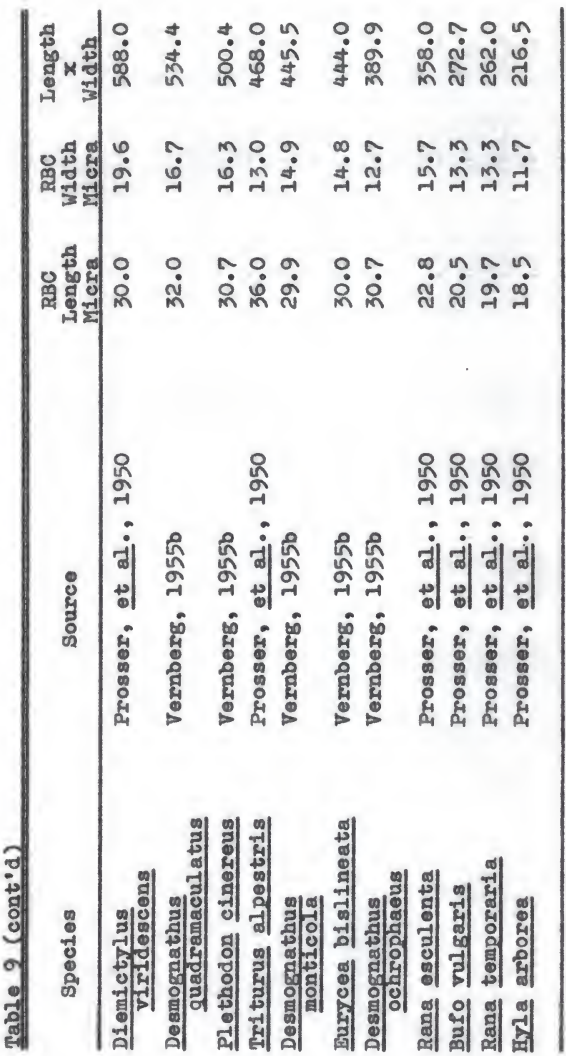




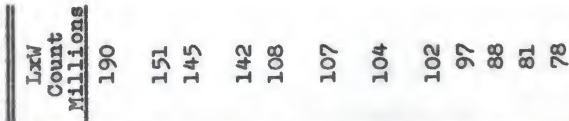

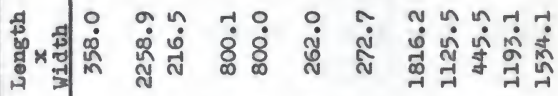

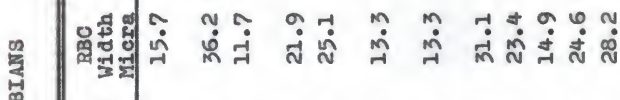

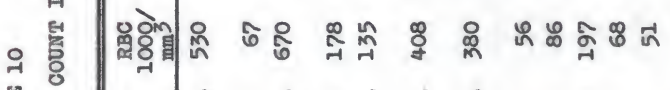

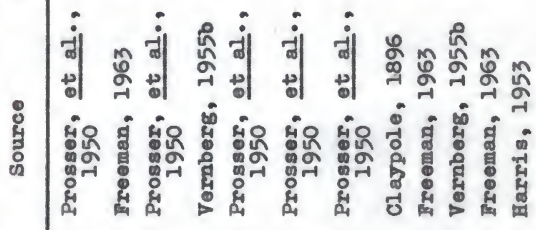

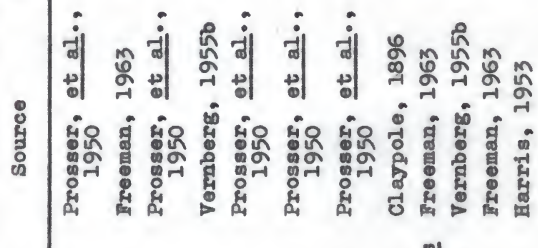

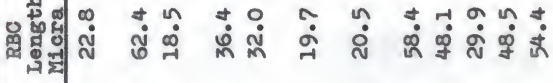

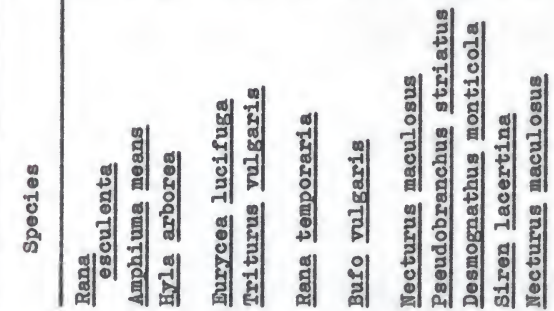$$
\text { 最是 }
$$ 


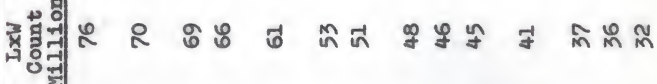

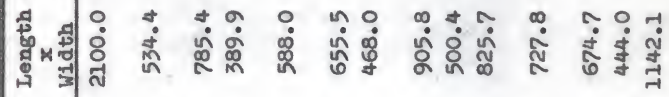

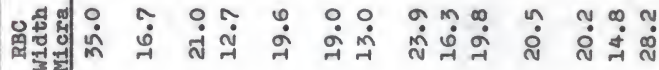

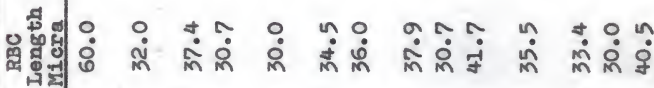

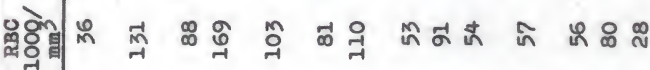

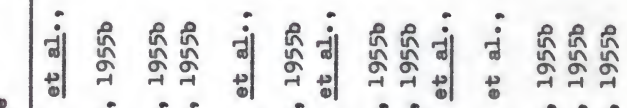

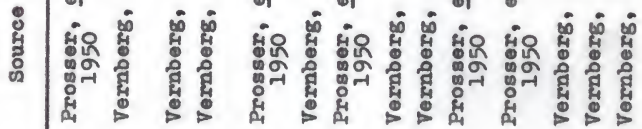


seem that the much shorter cell length as recorded in his data could be attributed either to a typographical error or perhaps to an exror in calculation in converting optical micrometer readings into micra.

Chang, Chen, and Chen (1943) and Harris (op. cit.) report a decrease in red cell count in Necturus as a result of starvation, thus the extremely low average of Vernberg's red cell counts in Necturus could be due to nutritional deflcieney in his specimens.

Vernberg (1955b) in his study of 12 species of salamanders said that there is a general correlation between cell size and body weight in that larger species have larger cells. However, he noted an exception to this in that the larger Ambjstoma tigrinum has smaller cells than the smaller Ambratoma maculatum. The usual inverse relationship of the species having the larger cells also having the smaller number of cells shows an exception in comparing Furycea lucifuga and Durycea bislineata.

The cell size and number in Pseudobranchus could be Interpreted as an exception to these generalities also if this genus were considered with the salamanders investigated. by Vernberg. Its body weight would be no greater than an average Gyrinophilus, Ambystoma, or Desmognathus, but 1 ts red blood cell size is greater than all of the amphibians except the large aquatic forms, Cryptobranchus, Proteus, 
Necturus, Amphiuma, and Siren. At the same time its cell count is higher than two species each of the Ambjstomidae, Salamandridae, and Plethodontidae.

Thus in its red blood cell dimensions, Pseudobranchus is grouped with its co-pamilial genus Siren and other giant aquatic salamanders in having the largest red blood cells among the vertebrates. It appears that the lasge red blood cell size of Pseudobranchus is a reflection of 1ts descent from larger sirenid forms. The known fossil Psoudobranchus (Goin and Auffenberg, 1955) were larger than the extant P. axanthus.

From the point of view of an increased surface-volume ratio it seoms that small and numerous erythrocytes are most effective as oxggen carriers. This condition is seen in the jumping, climbing, active anurans and in the endotherms. That Pseudobranchus retalns its anceatral giant erythrocytes in its present smaller body is indicative that there was no selective pressure on the oxpgen carrying capacity of the blood that would make smaller and more numerous cells a more efficient morphological adaptation.

The values of length times width counts of erythrocytes would give comparative figures for the available surface areas for transportation of oxpgen provided that hemoglobin activities of the various species are the same. McCutcheon and Hall (1937) have said that the oxpgen affintty 
of hemoglobins of varlous amphibians varies, the difference being correlated with respiratory mechanisms, hemopoietic apparatuses, limitations of the environment, and metabolic activities of the animals. In Table 10, where the animals are arranged in descending order of the length times width times count of the exythrocytes, there seems to be a lack of phylogenetic or ecological grouping except that the anurans are in the top one-third of the table.

\section{Hemoglobin Values}

Hemoglobin values of some represertative amphibians are presented in Table 11. As noted in the table the bloods of anurans are recorded as having higher hemoglobin contents than the caudate amphibians. Also notable is the discrepancy between the two values found for Necturus by different investigators. This is not particularly surprising considering the great range of values shown in the measurements of Pseudobranchus hemoglobin.

The coefficient of variation of 25.9 for the hemoglobin values of Pseudobranchus blood may not be as unrealistic as it seems at first. Unpublished data from Goin and Jackson on blood of Bufo terrestris show a coefficient of variation of 26.9 in hemoglobin count of the blood. Stuart (1951) in his comparison of hemoglobin values 
TABLE 11

HEMOGLOBIN CONTHNT OF AMPHIBIAN BLOOD

\begin{tabular}{|c|c|c|}
\hline Animal & Source & $\begin{array}{c}\mathrm{Hb}-\mathrm{gm} / 100 \mathrm{ce} \\
\text { Blood }\end{array}$ \\
\hline Bufo bocourt1 & Stuart, 1951 & 10.6 \\
\hline Bufo vilgarls & Prosser, et el., 1950 & 10.2 \\
\hline Erla axborea & Prosser, et el., 1950 & 10.2 \\
\hline$\frac{\text { Necturus }}{\text { neculosus }}$ & Prosser, et al., 1950 & 9.8 \\
\hline Rana esculents & Prosser, et al., 1950 & 9.5 \\
\hline Bufo marinus & Stuart, 1951 & 8.7 \\
\hline$\frac{\text { Salamandra }}{\text { maculata }}$ & Prosser, et al., 1950 & 8.0 \\
\hline$\frac{\text { Pseudobranchus }}{\text { striatus }}$ & Freeman, 1963 & 6.8 \\
\hline Salamandra atra & Prosser, et al., 1950 & 6.8 \\
\hline Priton alpestris & Prosser, et al., 1950 & 6.0 \\
\hline$\frac{\text { Necturus }}{\text { maculosus }}$ & Harr1s, 1953 & 4.2 \\
\hline
\end{tabular}


In Bufo marinus and Bufo bocourti had great ranges of 6.5$11.00 \mathrm{gm} / 100 \mathrm{cc}$ and 7.5-13.75 $\mathrm{gm} / 100 \mathrm{cc}$ for the two species, respectively. The range would have been even greater for B. marinus had Stuart not considered seven of his 79 individuals to be "anemics" and dropped them by statistical manouvers erom his analjsis.

Though the acid hematin test may not be the ideal method for definitive studies of amphibian blood it does give some comparative values when applied to enough different species or individuals of the same species. From mJ investigations it seems that Pseudobranchus blood has a hemoglobin value in the expected range of the caudate amphiblans and great differences between individuals are evident.

The mean hemoglobin value of pgeudobranchus was $6.8 \mathrm{gm} / 100 \mathrm{cc}$ of blood. Each gram of hemoglobln carries $1.34 \mathrm{ml}$ of oxggen at saturation (Kitchen and Pritchard, 1963) and therefore the oxygen capacity of Pseudobranchus hemoglobin could be expressed as 9.1 volumes per or $9.1 \mathrm{ml}$ per $100 \mathrm{cc}$ of blood.

In his book the Bcology and Iife History of the Common Frog Savage (1962) states, "The respiratory arrangements in tadpoles underline what I believe to be points of Pundamental importance in Anuran ecology - the great degree of specialized adaptation to the environment, which enables 
the different species to colonize habitats in great variety, from tree holes to puddles, from lakes to cow-ponds, from mountain streams to dxy land. The common feature of most of these habitats is that they confine the tadpoles within usually quite small limits. If the conditions in their pond turn out to be dangerous they cannot go in search of better ones, as animals that live on dry land or in the sea can do, but must possess reserve mechanisms that can be brought into play to deal with the often violent eluctuations in the habitats."

Similar conclusions are here proposed for the "respiratory arrangements" of Pseudobranchus. Its mechanisms for respiration, gills, skin, and lungs are utilized in different degrees when environmental changes occur. If the oxygen content of the water is lowered the gills of Pgeudobranchus expand. If the carbon dioxide of the water is high at the same time that the oxpgen tension is low the animal may respond by rising to the surface to gulp afr. If the pond goes dry Pseudobranchus can estivate in the mud and survive presumably on skin and pulmonary respiration alone. There seems to be no special adaptations in the blood of Pseudobranchus that set it apart from other amphibians.

The lower oxjgen and higher carbon dioxide of the water underneath the hyacinths due to the respiration of 
the organisms in the water are accentuated by the shading effect of the hyacinths which decreases the photosynthetic activity of hydrocotyl and other underwater plants. Thls low oxpgen and high carbon dloxide concentration increases the need for aerial respiration in Pseudobranchus. However, the hracinths afford a protective cover for the surfacing forays of the animals thus making it safer for them than If they surfaced in open water. The shading effect of the hyacinths keeps the water in a temperature range in which the oxygen consumption rate of Pseudobranchus is relatively low and oxygen solubility of the water relatively high. Pseudobranchus is well-adapted to the water hyacinth community of the prairie ponds. One important aspect of this adaptation is the possession of respiratory mechanisms which enable Pseudobranchus to survive severe fluctuations in the environment of its habitat. 


\section{SUMMARY}

A study was made of the respiratory behavior and physiology of Psoudobranchus striatus axanthus in conjunction with an investigation of the effect of the water hyacinth Fichornta crassipes on the physical environment of the ponds in which Pseudobranchus 1ivos.

A diurnal temperature differentiation in the ponds was measured in which the water under the hyacinth mats was up to $11^{\circ} \mathrm{C}$ cooler than the open water of the pond. The shading effect of the mats reduced the photosynthetic activity of the sub-hyacinth vegetation and thus the oxpgen content was lower and the carbon dioxide content was higher In the water under the hyacinths than in the open water. The hyacinths also contributed organic debris which decreased the depth of the pond and perhaps added organic acids which lowered the $\mathrm{pH}$ of the water in addition to the higher carbon dioxide content.

The rate of oxggen consumption of Pseudobranchus was a linear function of temperature at $15^{\circ} \mathrm{C}$ to $25^{\circ} \mathrm{C}$ and showed a $Q_{10}$ of 1.98 in that range. The rate of oxpgen consumption of Pseudobranchus was lower than those rates known for other caudate amphibians of comparable size. 
At $20^{\circ} \mathrm{C}$ the mean rate of oxygen consumption of five Pseudobranchus was $29.9 \mathrm{~mm}^{3} / \mathrm{gm} / \mathrm{hr}$. This low rate is a reflection of the generally sluggish activity of the animal.

Pseudobranchus responded to high carbon dioxide and low oxggen tensions in water by periodically surfacing to take alr into 1ts buccopharyngeal cavity and lungs. At high oxygen tensions it could respire beneath the surface with constricted gills. At intermediate carbon dioxide and oxggen tensions Pseudobranchus respired aquaticalig with its gills expanded and rarely surfaced to gulp air. It was able to survive on lung respiration alone in oxygen-depleted water and Individuals from which the gills had been removed could survive on cutaneous respiration alone in water of medium oxgren tensions.

The mean dimensions of $100 \mathrm{red}$ blood cells of Pseudobranchus were $48.1 \times 23.4$ micra and the mean of 15 red blood cell counts was 86,000 cells per cubic millimeter of blood. These cell dimensions were considerably larger than those recorded from other caudate amphibians of similar body weights. Red blood cell size in Pseudobranchus was most nearly similar to the red blood cell size in Siren lacertina, much larger animal than Pseudobranchus. The cell count was higher than those of many salamanders having cells of a smaller size than Pseudobranchus. 
The mean hemoglobin value for eight adult Pseudobranchus was 6.8 grams per $100 \mathrm{ce}$ of blood. The oxpgen capacity of the blood was calculated to be 9.1 volumes per cent per $100 \mathrm{cc}$ of blood. These values are in the ranges of most amphibians.

Pseudobranchus 1s adapted to meet 1ts respiratory needs in the water hracinth habitat by the utilization of its diverse resplratory mechanisms in different degrees as changes occur in the amounts of dissolved carbon dioxide and oxygen in 1ts environment. 


\section{IITERATURE CITED}

Allee, W. C. and R. Oesting. 1934. A critical examination of Winkler's method for determining alssolved oxygen in respiration studies with aquatic animals. Phjsiol. 2001. 7:509-541.

Angel, F. 1947. Vie et moeurs des amphibians. Par1s: Payot-Paris. 317pp.

Bishop, S. C. 1947. Handbook of salamanders. Ithaca: Comstock. xiv and 555pp.

Brattstrom, B. H. 1963. A preliminary review of the thermal requirements of amphiblans. Bcology. 44: 238-255.

Brattstrom, B. H. and W. N. McFarland. 1955. Notes on the behavior of the salamander Taricha torosa, under the influence of carbon d1oxlde. Behavior. 7:317-320.

Carr, A. F. 1940. A contribution to the berpetologs of Florida. Univ. of Fla. B101. Sc1. Ser1es 3:1-118.

Chang, Y. T., J. M. Chen and T. Chen. 1943. Induced poljcythemia in salamanders by cobalt, ascorbic acid, and other water-soluble vitamins. Arch. Blochem. $3: 235-239$.

Clappole, E. J. 1896. Notes on the comparative histology of blood and muscle. Proc. Amer. Micr. Soc. 18:49-70.

Cochran, D. M. 1961. Ifiving amphibians of the world. Garden City: Doubleday. 199pp.

Cochran, W. G. and G. M. Cox. 1957. Hxperimental des1gn. Hew York: John W1ley and Sons, xiv and 611pp.

Cohen, B. and A. H. Smith. 1919. The colorimetric determination of hemoglobin. A practical procedure. J. Biol. Chem. 39:489-496. 
Conant, R. 1958. A field guide to reptiles and amphibians. Boston: Houghton Mifflin Co. $x v$ and 366pp.

Czopek, J. 1962. Vascularization of respiratory surfaces in some caudata. Copela. 1962:576-587.

Dehadral, P. V. 1962. Respiratory function of the swimbladder of Notopterus (Iacepede). Proc. Zool. Soc. London. $1393341-357$.

Drastich, I. 1925. Veber das Leben der Salamandra-larven bel hohem und niedrigem Sauerstoffpartialdruck. $z$. vergl. Physiol. 2:632-651.

Etkin, W. 1934. The phenomena of anuran metamorphosis. II $\mathbb{B}$. Oxggen consumption during normal metamorphosis. Physiol. Zool. VII:129-148.

Evans, G. 1939. Factors Influencing the oxpgen consumption of several species of plethodontid salamanders in aerial and aquatic media. Bcology 20:74-95.

Freeman, J. R. 1958. Burrowing in the salamanders Psoudobranchus striatus and Siren lacertina. Herpetologica. $14: 130$. $15: 16$.

1959. A record-size dwarf siren. Herpetologica.

Fuhrman, G. J. and I. A. Fuhrman. 1959. Oxggen consumption of animals and tissues as a function of temperature. Jour. Gen. Phys1ol. 42:715-721.

Goin, C. J. 1941. The striped siren Psoudobranchus striatus. Masters thesis, Univ. of florida.

1942. A method for collecting the vertebrates assoclated with water hyacinths. Copeia. 1942:183184.

1943. The lower vertebrate fauna of the water hyacinth community of northern Florida. Proc. Fla. Acad. Sc1. $6: 143-153$.

- 1961. The growth and size of Siren lacertina. Herpetologica. 17:139.

- and W. Auffenberg. 1955. The fossil salamanders of the family Sirenidae. Buil. of Mus. of Comp. Z001. 113 (7):497-514. 
Goin, C. J. and O. B. Goin. 1962. Introduction to herpetology. San Franc1sco: W. H. Freeman and Co. ix and $341 \mathrm{pp}$.

Harper, F. 1935. Records of amphibians in the southeastern states. Amer. M1d. Nat. 16 (3):275-310.

Harris, J. P. 1953. Note on the blood of Necturus. Field and Laboratory. 21:147-148.

Helf, O. M. 1927. The rate of oxpgen consumption in five species of Amblystoma larvae. Jour. Bxp. Z001. 49: 353-361.

Hilton, W. A. 1952. The pulmonary respiratory system of salamanders. Herpetologica, 8:87-92.

Hutchison, V. H. 1961. Critical thermal maxima in salamanders. Phys101. Z001. 34:92-115.

Iitchen, H. and W. R. Pritchard. 1963. Physiology of blood. Department of Mediclne. Univ. of Fla. Col. Med. 1963:109-115.

Krogh, A. 1941. The comparative physiology of respiratory mechantsms. Philadelphia: University of Pennsylvania Press. 72pp.

Luckhardt, A. B. and A. J. Carlson. 1920. Studies on the visceral sensory nervous system. II Iung automatism and lung reflexes in the salamanders (Necturus and axolotl). Amer. Jour. Phys101. 54:122-137.

McCrady, E. 1954. A new species of Gyrinophilus (Plethodontidae) from Tennessee caves. Copela. $1954: 200-206$.

McCutcheon, F. H. and F. G. Hall. 1937. Hemoglobin in amphibia. Journ. Cell. Comp. Physiol. 9:191-197.

Neill, W. T. 1951. A new subspecies of sal amander, genus Pseudobranchus, from the Gulf Hammock region of Florida. PubI. Res. Div. Ross Allen's Rept. Inst. $1(4): 39-46$.

Noble, G. K. 1927. The value of 11fe history data in the study of the evolution of the Amphibia. Ann. N. I. Acad. Sc1. $30: 31-128$. 
Noble, G. X. 1931. The biology of the Amphibia. New York: McGraw-Hill Book Co. XIII and 577pp.

- and I. B. Richards. 1932. Bxperiments on the -88-laying of salamanders. Amer. Mus. Nov. 513:1-25.

Oesting, R. B. 1934. A modified Van Slyke method for the determination of dissolved oxygen and total carbon dioxide in water. Physiol. Zool. 7:542-549.

Prosser, C. I., D. W. Bishog, F. A. Brown, Jr. , T. L. Jahn, and V. J.'Wuiff. 1950. Comparative animal phys10logy. Ph1ladelphia: W. B. Saunders Co. $1 x$ and 888pp.

Savage, R. M. 1952. Ecological, physiological and anatomical observations on some species of anuran tadpoles. Proc. Zool. Soc. London. 122:467-514.

- 1962. The ecology and life history of the common Prog. Iew York: Hafner Publishing Co. vil and 221pp.

Smith, H. M. 1925. Cell size and metabolic activity in amphtbia. B10l. Bull. 48:347-378.

Smith, Hobart. 1960. Bvolution of chordate structure. How York: Holt Rinehart and Winston. xiv and 529pp.

Stuart, I. C. 1951. The distributional implication of temperature tolerances and hemoglobin values in the toads, Bufo marinus and Bufo bocourt1. Copeia. 1951: 220-22.

Vernberg, R. J. 1952. The oxggen consumption of two species of salamanders at different seasons of the jear. Physiol. 2001. 25:243-249.

1955a. Correlation of physiological and behavior Indexes of activity in the study of plethodon clnereus (Green) and Plethodon glutinosus (Green). Amer. Mid. Nat. 54:382-393.

1955b. Hematological studies on salamanders in relation to their ecologJ. Herpetologica. 11:129-133.

Welch, P. S. 1948. Iimnological methods. Philadelphia: The Blakiston Co. xv111 and $381 \mathrm{pp}$. 
Whitford, W. G. and V. H. Hutchison. 1963. Cutaneous and pulmonary gas exchange in the spotted salamander, Ambrstoma maculatum. Biol. Bull. 124:344-354.

W1lder, J. F. 1937. A correlation of results on oxggen consumption obtatined by the Winkler method and by respirameters, using the methods of Van slyke. Physiol. 2001. 10:464-472.

W1llmer, E. N. 1934. Some observations of the respiration of certain tropical fresh-water flshes. J. Bxper. Biol. 11:283-306. 


\section{BIOGRAPHICAI, SKETCE}

John Rlchardson Freeman was born August 24, 1927, at Murfreesboro, Tennessee. In Maj, 1945, he was graduated from Murfreesboro Central High School. From 1945 until 1946 he served in the Untted States Navy. He attended Middle Tennessee State College from 1946 unt1l 1948 and in June, 1950, he received the degree of Bachelor of Arts from the University of North Carolina with a major in zoology. He taught in Spring City High School, Tennessee from 1950 unt1l 1951. In June, 1953, he recelved the degree of Master of Arts from George Peabody College. From 1953 until 1955 he taught biolog at Jacksonville Junior college. In 1955 he onrolled in the Graduate School of the University of Florida. He hes worked as a graduate assistant in the Department of Blology and as a teaching assistant and halftime interim instructor in the Department of Biological Science. From September, 1959 until the present he has been an assistant professor in the biology department of the University of Chattanooga.

John R. Freeman is a member of the Association of Southeastern Blologists, the American Society of Ichthyologists and Herpetologists, the Herpetologists League, the Tennessee Academy of Sclence, Beta Beta Beta, and PhI S1gma. 
This dissertation was prepared under the direction of the chairman of the candidate's supervisory comittee and has been approved by all members of that committee. It was submitted to the Dean of the College of Arts and Sclences and to the Graduate Council, and was approved as partial fulfillment of the requirements for the degree of Doctor of Philosophy.

December 21, 1963

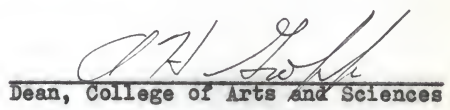

Dean, Graduate School

Supervisory Committee:
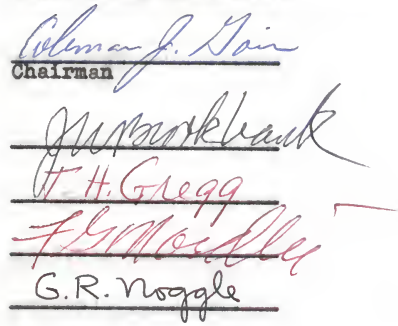